\title{
Chemical contaminants (trace metals, persistent organic pollutants) in albacore tuna from western Indian and south- eastern Atlantic Oceans: Trophic influence and potential as tracers of populations *
}

\author{
Chouvelon Tiphaine ${ }^{1,{ }^{*}}$, Brach-Papa Christophe ${ }^{1,2}$, Auger Dominique ${ }^{1}$, Bodin Nathalie ${ }^{3}$, \\ Bruzac Sandrine ${ }^{1}$, Crochet Sylvette ${ }^{1}$, Degroote Maxime ${ }^{3}$, Hollanda Stephanie J. ${ }^{4}$, Hubert Clarisse ${ }^{1}$, \\ Knoery Joel ${ }^{1}$, Munschy Catherine ${ }^{5}$, Puech Alexis ${ }^{6}$, Rozuel Emmanuelle ${ }^{1}$, Thomas Bastien ${ }^{1}$, \\ West Wendy ${ }^{7}$, Bourjea Jerome ${ }^{8}$, Nikolic Natacha ${ }^{6,9}$
}

\footnotetext{
${ }^{1}$ IFREMER, Unite Biogeochim \& Ecotoxicol BE, LBCM, Rue lle Yeu,BP 21105, F-44311 Nantes 03, France.

${ }^{2}$ IFREMER, Unite Littoral, LER PAC, Zone portuaire Bregaillon, BP 330, F-83507 La Seyne Sur Mer, France.

${ }^{3}$ IRD, UMR MARine Biodivers Exploitat \& Conservat MARBEC, Victoria, Seychelles.

${ }^{4}$ SFA, Victoria, Mahe, Seychelles.

${ }^{5}$ IFREMER, Unite Biogeochim \& Ecotoxicol BE, LBCO, Rue lle Yeu,Bp 21105, F-44311 Nantes 03, France.

${ }^{6}$ IFREMER, DOI, Rue Jean Bertho,BP 60, F-97822 La Port, La Reunion, France.

${ }^{7}$ Dept Agr Forestry \& Fisheries, Private Bag X2, ZA-8012 Cape Town, South Africa.

${ }^{8}$ IFREMER, UMR MARine Biodivers Exploitat \& Conservat MARBEC, Ave Jean Monnet,BP 171, F34203 Sete, France.

${ }^{9}$ ARBRE, F-97460 St Paul, La Reunion, France.
}

*Corresponding author : Tiphaine Chouvelon, email address : tiphaine.chouvelon@ifremer.fr

* Funding sources: This work was conducted in the framework of the GERMON project "N ${ }^{\circ} 759 / D M S O I / 2013$ " funded by the European Fisheries Funds EU FEP 2013-2015 and IFREMER.

\begin{abstract}
:
Albacore tuna (Thunnus alalunga) is a highly commercial fish species harvested in the world's Oceans. Identifying the potential links between populations is one of the key tools that can improve the current management across fisheries areas. In addition to characterising populations' contamination state, chemical compounds can help refine foraging areas, individual flows and populations' structure, especially when combined with other intrinsic biogeochemical (trophic) markers such as carbon and nitrogen stable isotopes. This study investigated the bioaccumulation of seven selected trace metals chromium, nickel, copper $(\mathrm{Cu})$, zinc $(\mathrm{Zn})$, cadmium $(\mathrm{Cd})$, mercury $(\mathrm{Hg})$ and lead - in the muscle of 443 albacore tunas, collected over two seasons and/or years in the western Indian Ocean (WIO: Reunion Island and Seychelles) and in the south-eastern Atlantic Ocean (SEAO: South Africa). The main factor
\end{abstract}


that explained metal concentration variability was the geographic origin of fish, rather than the size and the sex of individuals, or the season/year of sampling. The elements $\mathrm{Cu}, \mathrm{Zn}, \mathrm{Cd}$ and $\mathrm{Hg}$ indicated a segregation of the geographic groups most clearly. For similar sized-individuals, tunas from SEAO had significantly higher concentrations in $\mathrm{Cu}, \mathrm{Zn}$ and $\mathrm{Cd}$, but lower $\mathrm{Hg}$ concentrations than those from WIO. Information inferred from the analysis of trophic markers $(\delta 13 \mathrm{C}, \delta 15 \mathrm{~N})$ and selected persistent organic pollutants, as well as information on stomach contents, corroborated the geographical differences obtained by trace metals. It also highlighted the influence of trophic ecology on metal bioaccumulation. Finally, this study evidenced the potential of metals and chemical contaminants in general as tracers, by segregating groups of individuals using different food webs or habitats, to better understand spatial connectivity at the population scale. Limited flows of individuals between the SEAO and the WIO are suggested. Albacore as predatory fish also provided some information on environmental and food web chemical contamination in the different study areas.

\section{Graphical abstract}

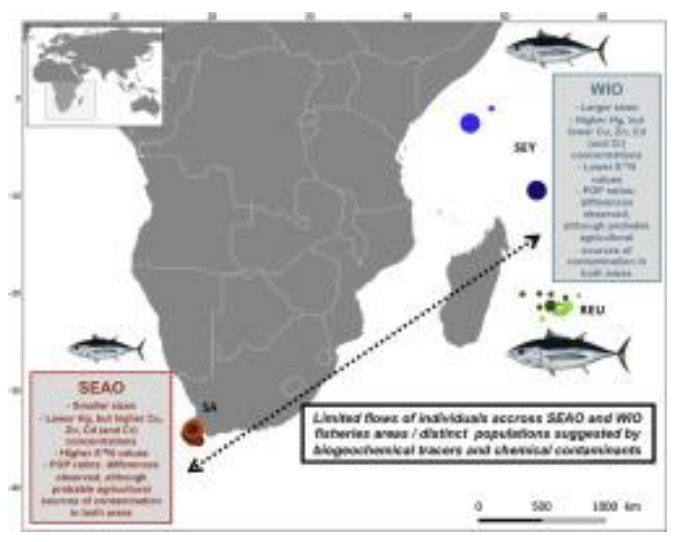

\section{Highlights}

- 443 albacore tunas were analysed for their muscle concentrations in trace metals. $\mathrm{Cu}, \mathrm{Zn}, \mathrm{Cd}$ and $\mathrm{Hg}$ were the elements that most segregated the different groups. Trophic markers and organic contaminants confirmed the segregation observed. Differences in trace metal bioaccumulation were linked to fish trophic ecology. - Inorganic elements can trace populations exploiting different food webs.

Keywords: Top predator, Bioaccumulation, Inorganic elements, Organic contaminants, Stable isotopes, Intrinsic markers 
Trace metals are inorganic elements that are naturally present on Earth. They have been used over a long time due to their properties such as mechanical resistance, electric or thermic conductivity, or biocidal properties. Since the industrial age, their increasing use in human activities has led to continuous release and contamination of all environmental compartments. Thus, trace metals are currently released into the environment from both natural (e.g., volcanism) and anthropogenic sources (e.g., industrial, urban, or agricultural). They reach the ocean through river inputs and atmospheric depositions, the atmospheric pathway at times transporting trace metals very far from the emission source (Mason, 2013). Some trace metals are recognized to be essential for organisms and form the basis of biochemicals, such as enzymes. However, they perform optimally in a relatively low range of concentrations and become either deficient or toxic at very low or high concentrations (e.g., copper $(\mathrm{Cu})$, zinc $(\mathrm{Zn})$ ). Alternatively, some elements have no known biological role and are recognized for their toxicity towards most organisms (e.g., cadmium $(\mathrm{Cd})$, mercury $(\mathrm{Hg})$, lead $(\mathrm{Pb})$ ), even at low concentrations (Mason, 2013). Taxa- and species-specific regulation mechanisms of metals have been described for both essential and non-essential elements, influencing their storage or elimination by organisms (Wang and Rainbow, 2010). Their transfer between biogeochemical compartments, their bioaccumulation in organisms and/or biomagnification in food webs finally depend on the speciation of elements, which determines their bioavailability in both abiotic (habitat) and biotic (food sources) environments of organisms (Neff, 2002; Rainbow, 2002). Contrary to trace metals, persistent organic pollutants (POPs) such as polychlorinated biphenyls (PCBs) and dichlorodiphenyl-trichloroethane (DDT) are almost exclusively from anthropogenic origin. They are manufactured for, and are used widely by commercial sectors such as industry and agriculture, which released them into the environment. POPs volatilize easily and can be transported through the atmosphere over wide distances, and deposited in areas far from their point of emission (Jones and de Voogt, 1999; Bogdal et al., 2013). Moreover, these chemicals or their metabolites have a strong persistence in ecosystems, and they are well documented to biomagnify in food webs and to be toxic for organisms (e.g., Verreault et al., 2008).

In aquatic organisms and more specifically in marine top predators such as marine mammals, seabirds or large pelagic fish, the trophic pathway represents the main pathway for the intake of both trace metals and POPs (e.g., Fisk et al., 2001; Wang, 2002; Mathews and Fisher, 2009). Individual trophic ecology can thus largely affect the contaminant concentrations measured in a given organism. This includes feeding area, trophic level, or the type of prey consumed (Lahaye et al., 2005; Choy et al., 2009; Ramos et al., 2013; Teffer et al., 2014), some prey accumulating more contaminants than others, for instance (e.g., Bustamante et al., 1998; Pulster et al., 2005). Understanding the mechanisms leading to bioaccumulation of contaminants and/or interpreting contaminant concentrations measured in biota thus requires a good knowledge of the consumers' feeding habits and ecology. 
116 Over the last decades, stable isotope analysis (SIA) of carbon $\left(\delta^{13} \mathrm{C}\right)$ and nitrogen $\left(\delta^{15} \mathrm{~N}\right)$ in biological 117 tissues has largely developed to study the trophic ecology of marine organisms such as top predators

118 (Kelly et al., 2000; Newsome et al., 2010). It effectively represents an alternative or complementary 119 tool to the traditional methods of dietary studies such as the analysis of stomach contents. $\delta^{13} \mathrm{C}$ values 120 are generally considered a conservative tracer of the primary producer at the base of the food web 121 supporting consumers, and consequently a tracer of their foraging habitat (France, 1995; Hobson, 122 1999). Alternatively, $\delta^{15} \mathrm{~N}$ values are generally used as a proxy of their trophic position (Post, 2002), 123 although the interpretation of $\delta^{15} \mathrm{~N}$ values should be food web-specific due to high variability in $\delta^{15} \mathrm{~N}$ 124 baseline values between ecosystems (Sherwood and Rose, 2005; Ménard et al., 2007; Chouvelon et al., 125 2012a).

126 More recently, the combined use of parameters (i.e. SIA, fatty acid profiles, chemical contaminants 127 including metals and/or POPs, etc.) measured in consumers' tissues as ecological tracers of marine 128 predators' trophic position, dietary preferences or foraging areas, has drastically increased (e.g., Fisk et 129 al., 2002; Iverson et al., 2004; Lahaye et al., 2005; Krahn et al., 2007; Mendez-Fernandez et al., 2013, 130 2017; Cresson et al., 2015). Based on the assumption "I am what I eat", such ecological tracers are 131 used to encompass the inherent difficulty of direct at-sea observations for these species. When 132 combined to other tools such as geolocation devices and tags, or biological data such as genetic and 133 morphological data, they may also be helpful in unravelling top predators' foraging strategies over 134 time, spatial dynamics (migrations), or the use of different resources or habitats by the different 135 populations of a given species (Ramos and González-Solís, 2012; Chouvelon et al., 2014; Cresson et 136 al., 2015). To the best of our knowledge, such a combined approach has not yet been used in tunas, 137 while these top predator fish represent an important commercially species harvested in the world's 138 Oceans.

139 The commercial catch of albacore tuna (Thunnus alalunga) is the highest globally among the 140 temperate tuna species and has contributed around $6 \%$ by weight of global tuna catches over the last 141 decade (FAO, 2016). The state and the assessment of albacore stocks vary geographically. The 142 estimated stock assessment has long been considered over-exploited in the South Atlantic Ocean 143 (SAO), and not over-exploited in the Indian Ocean (IO) (ICCAT, 2016; IOTC, 2016), although large 144 uncertainties remain (Guan et al., 2016) due to limited and low-quality data. Moreover, this species 145 has been poorly studied in the IO in comparison with other Oceans (Nikolic et al., 2016). In the Pacific 146 and Atlantic Oceans, the migration of albacore tunas between hemispheres is considered negligible 147 (Nakamura, 1969; Lewis, 1990; Arrizabalaga et al., 2004), influenced by global intra-ocean circulation 148 (e.g., oceanic gyres) that drives the oceanography of the northern and southern hemispheres. Due to 149 the absence of such structures in the IO, albacore has been managed as one unique stock in this region 150 (Chen et al., 2005), distributed between $5^{\circ} \mathrm{N}$ and $45^{\circ} \mathrm{S}$. Additionally, the tip of South Africa has long 151 been considered an impenetrable barrier for marine animals (Briggs, 1974). However, several recent 152 studies have demonstrated that gene flow occurs between the SAO and western Indian Ocean (WIO) 
for a number of species, including large vertebrates such as the green turtle (Bourjea et al., 2007), the scalloped hammerhead sharks (Duncan et al., 2006), and the tropical bigeye tuna (Durand et al., 2005). The question of connectivity between these two oceans for the albacore tuna is still pending. Indeed, a significant amount of juveniles of this species are caught each year in South African waters below $30^{\circ} \mathrm{S}$, and in the WIO between $30^{\circ} \mathrm{S}$ and $40^{\circ} \mathrm{S}$. Assessing the origin and the fate of these southern juveniles, and the potential links (gene flows, individual migrations, etc.) that may exist between the SAO and WIO stocks is a crucial issue for sustainable management of albacore tunas. In addition, trace element data on the albacore tuna remain scarce (e.g., Das et al., 2000 in the north Atlantic; Chen et al., 2014 and Hisamichi et al., 2010 in the north Pacific; Storelli et al., 2002 in the Mediterranean Sea), and more specifically in the study areas (e.g., Bodin et al., 2017).

In this general context, the main objectives of the present study were: 1) to characterise the contamination in several trace metals of albacore tunas caught in the WIO (Reunion Island and Seychelles) and in the south-eastern AO (SEAO; South Africa); 2) to determine the main factors influencing the bioaccumulation of the selected inorganic elements in tunas (e.g., effects of size, sex, season/year of sampling, geographic origin and food webs exploited); 3) to assess the potential of these trace metals as biogeochemical tracers of albacore tuna populations; 4) to evaluate the input of SIA (i.e. $\delta^{13} \mathrm{C}$ and $\delta^{15} \mathrm{~N}$ values, as trophic markers) and organic contaminants (i.e. selected POP ratios, as additional chemical tracers) for discriminating fish populations (i.e. do they corroborate, complement, or contradict the information provided by trace metals?). In addition, this study provides general information on the contamination state of the food webs supporting tunas in the different study areas.

\section{Materials and methods}

\subsection{Sampling}

A total of 443 albacore tunas were collected from June 2013 to July 2014 by commercial fisheries in three distinct areas in the WIO and the SEAO: 128 were caught by semi-industrial drifting longliners around La Réunion Island (REU), 118 by tuna purse-seine fisheries operating in Seychelles waters (SEY), and finally 197 by tuna pole fisheries in waters of South Africa (SA) (Fig. 1). Depending on the area considered, sampling was performed over two seasons (S1: austral summer November-

182 December, i.e. potential reproduction season of tunas; S2: austral winter April-July, i.e. potential 183 feeding period or post-reproduction period; Nikolic et al. 2016), and/or years (Y1: 2013; Y2: 2014), in order to account for the variability of environmental conditions and for the different life history traits of albacore tuna. All fishes analysed in the present study were already dead by the time of sampling. For each individual, the fork length (from the tip of the snout to the fork of the tail, FL in $\mathrm{cm}$ ) was 
dorsal musculature of each fish (sampled behind the head under the dorsal spine). All samples were frozen at $-20^{\circ} \mathrm{C}$, freeze-dried and ground into a fine powder until further chemical analyses.

\subsection{Trace metal analysis}

Trace metal analysis was performed on all muscle samples of albacore tuna $(\mathrm{N}=443)$. Total Hg analyses were carried out individually with an Advanced Mercury Analyser (ALTEC AMA 254), directly on subsamples (10-100 mg) of homogenised dry muscle tissue (untreated powder). For

$194 \mathrm{Hg}$ determination, the metal is evaporated by progressive heating up to $800^{\circ} \mathrm{C}$, then held under an oxygen atmosphere for $3 \mathrm{~min}$, and finally amalgamated on a gold net. Afterwards, the net is heated to liberate the collected $\mathrm{Hg}$, which is finally measured by atomic absorption spectrophotometry. $\mathrm{Hg}$ analyses were run according to a thorough quality control programme including the analysis of a certified reference material (CRM) IAEA-142 (mussel homogenate; International Atomic Energy Agency/IAEA).

For the analysis of the six other inorganic elements (Chromium (Cr), Nickel (Ni), $\mathrm{Cu}, \mathrm{Zn}, \mathrm{Cd}$ and $\mathrm{Pb}$ ), subsamples ( $\sim 200 \mathrm{mg}$ ) of homogenised dry muscle tissue were first digested with a mixture of $65 \%$ $\mathrm{HNO}_{3}, \mathrm{H}_{2} \mathrm{O}_{2}$ and milli-Q quality water, kept for a few hours at room temperature, and heated at $85^{\circ} \mathrm{C}$ on a heating block for $6 \mathrm{~h}$. After the mineralization process, each sample was completed with a known quantity of internal standards and diluted to $50 \mathrm{ml}$ with milli-Q quality water. Samples were re-diluted when necessary before analyses. Elemental analyses were finally carried out by Inductively Coupled Plasma-Mass Spectrometry (ICP-MS; Thermo X-Series I) and included the analysis of the two CRMs: IAEA-407 (whole fish homogenate; IAEA) and DOLT-3 (dogfish liver; National Research Council Canada).

Analytical performance details for the seven trace metals are summarized in Table 1. Metal concentrations are expressed in $\mathrm{mg} \cdot \mathrm{kg}^{-1}$ dry mass $(\mathrm{dm})$.

\subsection{Analysis of additional tracers}

212 From the total number of muscle samples of albacore collected for trace metal analysis, 335 were selected for SIA (96 from REU, 63 from SEY and 176 from SA), and 86 for POP analysis (43 from REU and 43 from SA).

215 SIA was performed according to the methods of Bodin et al. (2009) and Sardenne et al. (2016).

216 Briefly, around $2 \mathrm{~g}$ of dried and ground samples were treated by an Accelerated Solvent Extraction 217 system with dichloromethane. $\delta^{13} \mathrm{C}$ and $\delta^{15} \mathrm{~N}$ were analysed together on dried lipid-free samples using

218 a Delta V Advantage isotope ratio mass spectrometer interfaced to a Flash EA 1112 elemental analyser

219 (Thermo Scientific). Analytical precision for both $\delta^{13} \mathrm{C}$ and $\delta^{15} \mathrm{~N}$ was $<0.15 \%$ based on replicate 220 measurements of internal laboratory standards (acetanilide and peptone, Thermo Scientific). 
Details for POP analysis are found in Munschy et al. (2016). The concentrations and profiles of 18 PCB congeners (namely, the 6 indicators congeners CB-28; $-52 ;-101 ;-138 ;-153 ;-180$, and the 12 dioxin-like congeners $-77 ;-81 ;-105 ;-114 ;-118 ;-123 ;-126 ;-156 ;-157 ;-167 ;-169 ;-189)$ were determined together with DDT compounds (namely, $p, p^{\prime}$-DDT and $o, p^{\prime}$-DDD, and its main degradation products $o, p^{\prime}$-DDD, $p, p^{\prime}$-DDD, and $p, p^{\prime}$-DDE).

\subsection{Data treatment}

Statistics were only applied on trace metals for which almost $80 \%$ of individuals presented raw concentrations above the limits of quantification (LQ). These elements are further called "elements $>\mathrm{LQ}$ ", and $\mathrm{Pb}$ and $\mathrm{Ni}$ were thus excluded from data treatment and statistical analyses (Table 1). All figures and statistics were performed using the software R version 2.15.2 (R Development Core Team, 2012), except the map of sampling locations (Fig. 1) that was done using ArcGIS software (www.arcgis.com).

In the case of POPs, whose detailed results were recently published (Munschy et al., 2016), only three ratios were considered here for comparison with trace metals, due to their ability to trace potential contamination sources:

- Sum DDTs/Sum PCBs, where "Sum PCBs" corresponds to the sum of the concentrations of the 18 PCB congeners identified in albacore muscle samples, and "Sum DDTs" to the sum of the two parent DDT compounds and their three main metabolites. This ratio can generally distinguish the influence of sources from agricultural origin (when largely $>1$ ) vs. sources from industrial origin (Yogui et al., 2003; Lailson-Brito et al., 2011).

- $p, p^{\prime}-\mathrm{DDT} / p, p^{\prime}-\mathrm{DDE}$. This ratio can be used as a tracer of the residence time and degree of degradation of DDT in the environment, and consequently to distinguish new vs. old DDT sources (Suárez et al., 2013). - o, $p^{\prime}-\mathrm{DDT} / p, p^{\prime}-\mathrm{DDT}$. This ratio can trace the DTT origin (close to the technical mixture $(0.2-0.3)$, or not; Kalantzi et al., 2001).

\subsubsection{Classical statistics}

First, mean values in body sizes (FL), trace metal concentrations, $\delta^{15} \mathrm{~N}$ and $\delta^{13} \mathrm{C}$ values and POP ratios were submitted to parametric Student t-tests or non-parametric Mann-Whitney-Wilcoxon tests to assess i) differences between males and females (within a given season/year and in a given area), and ii) differences between seasons/years (in a given area). Differences between geographic areas were checked using Kruskal-Wallis tests (KW) followed by multiple comparison tests with Holm's adjustment method, because data never satisfied parametric conditions. All of the mean comparison tests were applied on raw data as well as size-normalised data (i.e. normalised to a $95 \mathrm{~cm} \mathrm{FL}$ individual) to account for the high variability in fish sizes between areas (Table 2). The level of significance for statistical analyses was always set at $\alpha=0.05$. 


\subsubsection{Generalized modelling}

257 To further estimate the effect of potentially confounding explanatory variables on the variability of trace metal concentrations (i.e. body size, trophic position (through $\delta^{15} \mathrm{~N}$ ), sex, season/year of sampling, and area), generalized modelling (considering each trace element separately) was applied using the mgcv package in R. Data effectively showed a marked departure from normality in most cases, preventing the application of multiple linear regressions.

Assuming potential migrations of fishes between areas and seasons and/or years, the two factors "area" and "season/year of sampling" were not considered separately in the models, as it could have been done in the case of true "nested data" (e.g., three areas considered, in which two seasons and/or years have been sampled). Indeed, with regard to potential flows of individuals between areas and seasons, S1 and S2 in the same area may be totally disconnected. The combination "Area/Season and/or Year of sampling" (Area/S-Y) was thus considered a single factor in the models, including 6 modalities: REU/S1, REU/S2, SEY/S2-Y1, SEY/S2-Y2, SA/S1 and SA/S2. FL (when considering size-related trends; $\mathrm{N}=443$ individuals) or $\delta^{15} \mathrm{~N}$ values (when considering trophic position-related trends; $\mathrm{N}=335$ ) were treated as the continuous explanatory variable in the models, while Sex and Area/S-Y were treated as categorical explanatory variables and/or added as an interaction term (for Area/S-Y).

273 Generalized Additive Models (GAMs), representing flexible non-parametric generalizations of (multiple) linear regressions, were first tested. They can capture and model both linear and complex non-linear relationships (Zuur, 2012), and as such they are said to be "data-driven" methods. GAMs were fitted on raw concentrations, with a Gamma distribution and a log link function. Applying GAMs on log-transformed concentrations directly (with a Gaussian distribution and an identity link function) substantially improved the models, as it is generally the case when dealing with contaminant data such as trace metals (e.g., Pierce et al., 2008; Mendez-Fernandez et al., 2013; Chouvelon et al., 2014). However, as the modelled trends with FL or $\delta^{15} \mathrm{~N}$ appeared to be linear, Generalized Linear Models (GLMs) were finally applied. As in the case of GAMs, GLMs were first fitted on raw concentrations with a Gamma distribution and a log link function. However, Gaussian GLMs on log-transformed concentrations with an identity link function also gave slightly better results and were thus kept.

Differences between sexes were tested in the first models, but since there was no effect for most of the trace metals and conditions (see also boxplots and classical statistics; Fig. 2), we removed the factor Sex from the final GLMs. The general forms of the models performed for each trace metal were thus: Results (fitted values) of the models were plotted on observed (log-transformed) data. Final models parameters (estimates, p-values, etc.) are given in supplementary material (Appendix A and Table A.1). For each model, we retained the variables that improved the relative goodness of fit in the 
was not significantly different between the last two nested models, the simplest model was preferred (Zuur et al., 2007). Finally, a model validation was systematically applied by checking normality and homogeneity in model residuals, with no violation of independence (Zuur et al., 2007; Zuur, 2012). Models not complying with all of these assumptions were not presented (i.e. for $\mathrm{Cd}$ ). The percentage of total deviance explained (DE) by each final model was calculated as follows: Explained deviance $=$ ((Null model deviance - final model residual deviance)/Null model deviance)*100, with the null model that only contained the intercept terms (Mendez-Fernandez et al., 2013).

\subsubsection{Multivariate analyses}

Different principal component analyses (PCAs) were performed to: i) identify relationships among the different types of chemical components analysed and included in the different PCAs (trace metals, and/or trophic markers $\left(\delta^{13} \mathrm{C}, \delta^{15} \mathrm{~N}\right)$, and POP ratios); ii) apprehend global profiles of contamination of the different groups of individuals analysed (i.e. contaminants considered together, and not separately as in previous data treatment). Moreover, these PCAs assessed of the potential of individual variables and/or of the combination of variables to trace the different groups of individuals. As such, the PCA 1 included all individuals for which trace metals were analysed $(\mathrm{N}=443)$; the PCA 2 included individuals for which both trace metals and trophic markers $\left(\delta^{13} \mathrm{C}\right.$ and $\delta^{15} \mathrm{~N}$ values) were analysed $(\mathrm{N}=335)$; and the PCA 3 included individuals analysed for trace metals and POP ratios $(\mathrm{N}=86)$. All PCAs were based on correlation matrices and normalised data for each variable included (i.e. data centred and divided by the standard deviation).

Finally, to further evaluate the potential of trace metals and/or their combination with trophic markers (i.e. larger datasets, and datasets including the three areas) in discriminating individuals from different geographic origin, discriminant analyses (DAs) were performed. DAs were also performed on datasets that included only the two close areas, REU and SEY in the WIO, to evaluate how they discriminate. As for PCAs, DAs used normalised data. Correlation coefficients between the discriminant functions and each of the original variables included in DAs - also called canonical correlation coefficients (ccc) - were used to assess the relative importance of each variable for the discrimination of individuals along the axes (Zuur et al., 2007).

\section{Results}

Characteristics of the albacore tunas considered in this study and the mean trace metal concentrations ( \pm standard deviation) measured in the muscle are given in Table 2. $100 \%$ of individuals from REU and $88 \%$ from SEY had FL $\geq 90 \mathrm{~cm}$ (min-max: $90-113 \mathrm{~cm}$ and $82-108 \mathrm{~cm}$ for REU and SEY, respectively), and females were significantly smaller than males $(\mathrm{p}<0.001$ for both REU/S1 and REU/S2; $p=0.022$ and $p=0.001$ for SEY/S1-Y1 and SEY/S2-Y2, respectively). Individuals from SA (min-max: 74-118 cm FL) were smaller on average than those from REU and SEY (Table 2), with 
most of the individuals having $\mathrm{FL}<90 \mathrm{~cm}$ ( $72 \%$ of individuals) and the majority of the fish with $\mathrm{FL} \geq 90 \mathrm{~cm}$ that were captured in S2 (Table 2). No significant size difference between sexes was found for SA individuals ( $\mathrm{p}=0.608$ and $\mathrm{p}=0798$ for SA/S1 and SA/S2, respectively).

Overall, Cr individual concentrations varied between $0.32 \mathrm{mg} \cdot \mathrm{kg}^{-1} \mathrm{dm}$ and $0.74 \mathrm{mg} \cdot \mathrm{kg}^{-1} \mathrm{dm}$ (minmax), while the range of values was $<0.03-0.28 \mathrm{mg} \cdot \mathrm{kg}^{-1} \mathrm{dm}$ for $\mathrm{Ni}$ (i.e. $<\mathrm{LQ}-0.28 \mathrm{mg} \cdot \mathrm{kg}^{-1} \mathrm{dm}$ ), $0.38-$ $3.67 \mathrm{mg} . \mathrm{kg}^{-1} \mathrm{dm}$ for $\mathrm{Cu}$, and $6.7-77.5 \mathrm{mg} \cdot \mathrm{kg}^{-1} \mathrm{dm}$ for $\mathrm{Zn}$. For non-essential elements, concentrations varied between $<0.05 \mathrm{mg} . \mathrm{kg}^{-1} \mathrm{dm}$ and $1.55 \mathrm{mg} . \mathrm{kg}^{-1} \mathrm{dm}$ for Cd, 0.386-4.665 mg. $\mathrm{kg}^{-1} \mathrm{dm}$ for $\mathrm{Hg}$, and $<0.05-0.29 \mathrm{mg} \cdot \mathrm{kg}^{-1} \mathrm{dm}$ for $\mathrm{Pb}$ (Table 2).

\subsection{Differences in trace elements between sexes, seasons/years, and areas}

Among the five elements analysed $>$ LQ, with the raw data considered, significant differences between sexes were only observed in one case for $\mathrm{Zn}$ (with females on average presenting slightly higher values than males in REU/S2) and in some cases for $\mathrm{Hg}$ (slightly higher concentrations measured in males than in females in REU/S2, SEY/S2-Y2, SA/S1). Some differences were also observed for $\mathrm{Cr}$ (with females presenting slightly higher values than males) when FL-normalised data were used (Table 2; Fig. 2). Differences between seasons/years of sampling were more often significant than between sexes and were very similar whether raw or FL-normalised data were used, although no general pattern appeared. Indeed in REU, there was no significant difference between seasons for $\mathrm{Hg}$, but significantly lower concentrations in $\mathrm{Cr}, \mathrm{Cu}, \mathrm{Zn}$ and $\mathrm{Cd}$ were found in individuals from $\mathrm{S} 1$ than in individuals from S2. In SEY, significantly lower concentrations in $\mathrm{Cr}$ and $\mathrm{Hg}$, associated with slightly higher concentrations in $\mathrm{Cu}, \mathrm{Zn}$ and $\mathrm{Cd}$ were found in individuals captured the first year (S2-Y1) relative to those captured at the second year (S2-Y2). Finally in SA, significantly higher concentrations in $\mathrm{Cu}, \mathrm{Zn}$ and $\mathrm{Cd}$, along with significantly lower concentrations in $\mathrm{Cr}$ and $\mathrm{Hg}$ were measured in individuals from S1 compared with individuals from S2 (Table 2; Fig. 2). Concerning geographical differences, for all elements except $\mathrm{Cr}$, the significant differences observed also remained similar whether raw or FL-normalised data were considered. Trace metal concentrations measured in individuals from the three areas were always significantly different in $\mathrm{Cu}, \mathrm{Zn}$ and $\mathrm{Hg}$, in line with the order of concentrations: $\mathrm{SA}>\mathrm{REU}>\mathrm{SEY}$ for $\mathrm{Cu}$ and $\mathrm{Zn}$; and $\mathrm{REU}>\mathrm{SEY}>\mathrm{SA}$ for $\mathrm{Hg}$. For $\mathrm{Cd}$, mean concentrations differed significantly only between individuals captured in the WIO and those caught in the SEAO (i.e. similar and lower concentrations on average in REU and SEY vs. SA). Cr showed no significant difference between areas when considering raw data, while the order of concentrations was SA $>$ REU $>$ SEY when considering size-normalised data (Table 2; Fig. 2). Finally, although statistical tests could not be applied due to a large number of individuals below LQ for $\mathrm{Ni}$ and $\mathrm{Pb}$, slightly higher $\mathrm{Ni}$ concentrations were observed in individuals from SA (Table 2). In fact, despite the low concentrations observed, most individuals from SA presented Ni concentrations $>$ LQ, while this element was poorly detected in the muscle of individuals from REU and SEY. 
Considering the five trace elements in a single analysis, the PCA 1 corroborated the low influence of sex in explaining metal concentrations variability, while the sampling season and/or sampling year (especially for SA individuals), as well as the geographic origin, were much more significant factors. As such, the first two axes of the PCA 1 explained $70.1 \%$ of the variability observed in the dataset. The elements $\mathrm{Cu}, \mathrm{Zn}, \mathrm{Cd}$ and $\mathrm{Hg}$ (in the order), and $\mathrm{Cr}$ to some extent (i.e. for SA individuals), contributed the most to the cluster of individuals belonging to different groups, and consequently, to the dispersion of individuals captured in the different areas and/or sampled at different seasons/years (Fig. 3). With the five trace metals $>$ LQ included, the DAs 1 and 2 further evidenced the significance of $\mathrm{Cu}, \mathrm{Zn}, \mathrm{Cd}$ and $\mathrm{Hg}$ (in that order) in clearly classifying individuals into the three areas. $\mathrm{Cu}$ also appeared to be a significant discriminant element between individuals from REU vs. SEY (Table 3).

\subsection{Size (FL)- and $\delta^{15} \mathrm{~N}$-related trends}

In the final GLMs performed, the total deviance explained (DE) in log-transformed metal concentration variability was quite high, ranging between $45.9 \%$ (for $\delta^{15} \mathrm{~N}$-related trends in $\mathrm{Hg}$ variability) and $84.3 \%$ (for FL-related trends in $\mathrm{Cu}$ variability). The AIC scores were systematically lower in models performed with FL as single continuous explanatory variable than in those with $\delta^{15} \mathrm{~N}$ (details in Appendix A and Table A.1).

Considering final models with FL, the effect of the factor Area/S-Y was always highly significant. The effect of size (FL) was significant for $\mathrm{Cr}$ and $\mathrm{Cu}$ only ( $\mathrm{p}=0.010$ and $\mathrm{p}<0.001$ respectively), despite a low $\mathrm{p}$-value also observed for $\mathrm{Hg}(\mathrm{p}=0.075)$. The interaction term (i.e. model assuming that the form of the relationship between (log-transformed) concentrations and FL can be different between modalities of the factor Area/S-Y) was significant for $\mathrm{Cr}$ and $\mathrm{Hg}$ only (p-values $<0.05$ ). Overall, GLMs results indicated i) variable trends for $\mathrm{Cr}$ (i.e. decreasing or increasing concentrations with increasing size of individuals), depending on the modality of the factor Area/S-Y; ii) a trend to decreasing $\mathrm{Cu}$ concentrations with increasing size of individuals; iii) no clear size-related trends for $\mathrm{Zn}$ and $\mathrm{Cd}$, although no model complying with model validation could be kept for $\mathrm{Cd}$; and iv) a slight trend to enhanced $\mathrm{Hg}$ bioaccumulation with increasing FL, especially for the modalities of the factor Area/S-Y with a large size range (Fig. 4). GLMs also revealed that for similar-sized individuals, SA individuals had significantly higher (log-transformed) concentrations in $\mathrm{Cu}$ and $\mathrm{Zn}$ than those from REU and SEY. For similar-sized individuals, those sampled in S2 in SA also had significantly higher Cr concentrations than all other individuals (Fig. 4; Appendix A and Table A.1). For similar-sized individuals sampled in REU, those captured in $\mathrm{S} 2$ had higher $\mathrm{Cu}$ and $\mathrm{Zn}$ concentrations than those sampled in S1, and had also higher $\mathrm{Cu}$ and $\mathrm{Zn}$ concentrations than individuals from SEY. Finally, there was no significant difference between individuals from S2-Y1 and S2-Y2 individuals in SEY 
In the final models with $\delta^{15} \mathrm{~N}$, the effect of the factor Area/S-Y in explaining metal variability was still highly significant for the four elements complying with model validation. As for models with FL, the effect of $\delta^{15} \mathrm{~N}$ was slightly significant for $\mathrm{Cr}$ and $\mathrm{Cu}$ only ( $\mathrm{p}=0.010$ and $\mathrm{p}=0.027$ respectively), despite a quite low $\mathrm{p}$-value also observed for $\mathrm{Hg}(\mathrm{p}=0.090)$. The interaction term was only significant for $\mathrm{Cr}$ (all p-values $<0.05$ ). A slight trend to enhanced concentrations with increasing $\delta^{15} \mathrm{~N}$ values was predicted for $\mathrm{Cu}$, and to a lesser extent $\mathrm{Zn}$ and $\mathrm{Hg}$, and variable trends for $\mathrm{Cr}$. Overall, for individuals with similar- $\delta{ }^{15} \mathrm{~N}$ values, geographical and seasonal/inter-annual differences in metal concentrations were analogous to those for similar-sized individuals (Fig. 4, Appendix A and Table A.1).

\subsection{Stable isotope values and POP ratios}

406

407

$\delta^{13} \mathrm{C}$ values varied between $-18.50 \%$ and $-16.30 \%$, while the range in $\delta^{15} \mathrm{~N}$ values was $10.71-15.11 \%$ o (Table 4). Concerning $\delta^{13} \mathrm{C}$ values, a significant difference between sexes (all p-values $<0.05$ ) was observed in REU only but for both sampling seasons, with males presenting on average higher values than females. Significant differences between seasons/years of sampling were found within the three areas considered (all p-values $<0.01$ ), with individuals sampled at S2 (or S2-Y2 for SEY) having higher $\delta^{13} \mathrm{C}$ values. No difference in $\delta^{13} \mathrm{C}$ was found between individuals from REU and SA, while SEY individuals presented slightly lower $\delta^{13} \mathrm{C}$ values. For $\delta^{15} \mathrm{~N}$ values, there was generally no significant difference between sexes and seasons/years of sampling. As in the case of metallic contamination, the spatial influence was more important. $\delta^{15} \mathrm{~N}$ values significantly differed between individuals captured in the WIO and those caught in the SEAO (i.e., similar and lower concentrations on average in REU and SEY, vs. SA). Finally, within each group of individuals considered, no correlation was found between isotope values and size of individuals (results not shown).

POP ratios were investigated in selected individuals from REU and SA sampled in S1 (Table 4). No differences were found between sexes in SA individuals. In REU, the "Sum DDTs/Sum PCBs" and the “ $p, p$ '-DDT/ $p, p$ '-DDE" ratios were significantly lower in males than in females, while no sexual difference was observed for the "o, $p$ '-DDT/ $p, p$ '-DDT" ratio. Similarly to metal contamination, significant differences between geographic areas were evidenced. Individuals from REU presented significantly lower values of the " $p, p$ '-DDT/p,p'-DDE” ratio and higher values of the "o,p'-DDT/p,p'DDT" ratio, although no spatial difference was found for the "Sum DDTs/Sum PCBs" ratio.

Finally, the PCAs 2 and 3 (including the five trace metals $>$ LQ, and the trophic markers or POPs) confirmed the results from PCA 1 in terms of clustering of individuals belonging to different groups. As such, in all PCAs performed, individuals from SA clearly segregated from individuals from REU and SEY, and seasonal differences among individuals from SA were further evidenced in PCA 2 (including trophic markers). The variability explained by the first two axes of the PCAs 2 and 3 (63.0 and $65.7 \%$, respectively) was in the same order of PCA 1. Lastly, the DAs 3 and 4 (including trace metals + trophic markers) emphasized the highly significant contribution of $\delta^{15} \mathrm{~N}$ values in 
discriminating individuals from the three different areas (i.e. increasing the percentage of wellclassified individuals for each area), along with the significant contribution of $\mathrm{Cu}, \mathrm{Zn}, \mathrm{Cd}$ and $\mathrm{Hg}$ (Table 3).

\section{Discussion}

\subsection{Fish size differences between areas}

Albacore has an estimated length at 50\% maturity (L50) of around $90 \mathrm{~cm}$ FL in all Oceans, apart from the Mediterranean Sea where estimates are smaller (Juan-Jordá et al., 2016). More recently in the WIO, the L50 of female albacores was estimated at $85.3 \pm 0.7 \mathrm{~cm}$ FL (mean \pm standard error; Dhurmeea et al., 2016). In REU and SEY, almost all individuals had FL $\geq 90 \mathrm{~cm}$ and were thus mature individuals. In both areas, the significant difference in fish sizes between adult males and females (with females being significantly smaller than males) was consistent with the documented sexual dimorphism in this tuna species (e.g., Karazulak et al., 2011; Dhurmeea et al., 2016). Alternatively, although some fish sampled in SA were $\mathrm{FL} \geq 90 \mathrm{~cm}$ (especially during S2), most individuals from this area were immature, probably explaining the absence of significant size difference between sexes in SA. More generally, further consideration of size (FL) in statistical analyses and interpretation of trace metal concentrations was therefore crucial, to avoid potential masking of other important factors in contamination differences (e.g., the geographic factor).

\subsection{General trends in trace metal concentrations and confrontation to health guidelines}

Overall, $\mathrm{Ni}$ and $\mathrm{Pb}$ concentrations were very low in all individuals analysed (mostly $<\mathrm{LQ}$ ), while concentrations in $\mathrm{Cr}, \mathrm{Cu}, \mathrm{Zn}, \mathrm{Cd}$ and $\mathrm{Hg}$ were more variable between areas (see below). For the three non-essential elements $\mathrm{Cd}, \mathrm{Hg}$ and $\mathrm{Pb}$, the European Commission (EC) fixed the following safety concentrations in tuna flesh (in wet mass, wm): $0.10 \mathrm{mg} \cdot \mathrm{kg}^{-1}$ wm for Cd, $1.00 \mathrm{mg} . \mathrm{kg}^{-1}$ wm for $\mathrm{Hg}$, and $0.30 \mathrm{mg} \cdot \mathrm{kg}^{-1} \mathrm{wm}$ for $\mathrm{Pb}$ (EC, 2006). Considering 70\% moisture content in tuna flesh (Kojadinovic et al., 2006; Munschy et al., 2016), this corresponds to maximum safety concentrations of $0.33 \mathrm{mg} . \mathrm{kg}^{-1}$ in dry mass $(\mathrm{dm})$ for $\mathrm{Cd}, 3.33 \mathrm{mg} \cdot \mathrm{kg}^{-1} \mathrm{dm}$ for $\mathrm{Hg}$, and $1.00 \mathrm{mg} \cdot \mathrm{kg}^{-1} \mathrm{dm}$ for Pb. These limits are indicated in Fig. 2 for $\mathrm{Cd}$ and $\mathrm{Hg}$. Pb concentrations measured in all tunas from the present study were far below EC health guidelines. For Cd, 67 (34\%) on the 197 individuals sampled in SA (both males and females and mostly from S1) displayed concentrations above the EC guidelines. Seven individuals (nearly 6\%) of the 118 sampled in SEY also had Cd concentrations above the guidelines, while none of the individuals from REU were of a similar concern. Finally for $\mathrm{Hg}$, only six individuals of the 443 analysed, that were of a larger size class collected in REU and SA, presented concentrations slightly above the safety limits. 
Hence globally, trace metal concentrations measured in the present study were in the same order of magnitude, or even in the low range of contamination concentrations by metallic elements compared to those reported in the literature for large pelagic fish such as tuna species worldwide, including albacore (e.g., Storelli et al., 2002, 2005; Kojadinovic et al., 2006, 2007; Choy et al., 2009; Chen et al., 2014; Ruelas-Inzunza et al., 2014; Bodin et al. 2017; and associated references). Similar observations were made in the case of POPs (Munschy et al., 2016), emphasizing a global low impact of anthropogenic contaminants in albacore tuna in the study areas.

\subsection{Significant factors affecting trace metal bioaccumulation}

473 Categorical factors explaining the variability in trace metal concentrations showed the following order 474 of influence: sex $<$ season/year of sampling $<$ geographic area. The influence of the continuous factors 475 FL (fish size) and $\delta^{15} \mathrm{~N}$ was intermediate, depending on the element considered.

476 The low effect of sex for most of the elements likely suggests poor elimination of trace metals during reproduction, contrary to organic contaminants for which this phenomena has been widely documented in adult females in particular (e.g., Jones and de Voogt, 1999; Bodiguel et al., 2009; Munschy et al., 2016). This may be nuanced in the case of $\mathrm{Hg}$, for which differences between sexes were more often significant, although differences in $\mathrm{Hg}$ concentrations between males and females may be also due to sexual differences in the trophic ecology (e.g., type of prey, trophic level). However, potential sexual differences in trophic ecology were not supported by stable isotope values (i.e. no sexual differences revealed in $\delta^{15} \mathrm{~N}$ values; Table 4), though different prey compositions can lead to similar isotopic signatures in a predator's tissues (Bearhop et al., 2004).

Within each ecosystem and especially those where fish with a large size range could be collected, $\mathrm{Hg}$ was the only element for which a trend to higher $\mathrm{Hg}$ concentrations with increasing size was found, while the trend was generally inverse or null for the other elements. The influence of the age of organisms (for which individual size may be generally considered a proxy) on $\mathrm{Hg}$ bioaccumulation in muscle is effectively a well-documented phenomenon. This is due to the very low elimination of this metal over time once it is linked to sulfhydryl groups of muscular proteins (Wang and Wong, 2003). The influence of individual trophic position (here regarded through $\delta^{15} \mathrm{~N}$ values within a specific ecosystem) - which generally increases with age, size and body mass in fish - was also expected, because of the known biomagnification of $\mathrm{Hg}$ in food webs (Gray, 2002; Chen et al., 2008). Alternatively, for the other trace metals, there is still no consensus on a potential increase in the concentrations observed with size or trophic level of organisms, nor biomagnification in food webs; although some authors reported such phenomenon in tuna species (Ruelas-Inzunza et al., 2014) and in particular cases in both marine and freshwater food webs (Wang, 2002, Croteau et al., 2005; Cheung et Wang, 2008). On the contrary, the present results (such as those for $\mathrm{Cu}$ ) rather suggest a dilution of 
variability observed are more probably due to differences in the trophic ecology of individuals or populations. In all analyses performed, the significance of geographic origin for explaining variability in metal concentrations was effectively the highest, and notably once the effect of size had been taken into account. Due to the large predominance of the trophic pathway for the intake of metallic contaminants in marine organisms (Wang, 2002) and in top predators in particular, geographic differences in tuna trace metal concentrations are therefore most likely due to differences in the different types of prey and/or food webs exploited.

As a direct comparison, concentrations of several trace metals in different tissues were reported for the yellowfin tuna T.albacares in the WIO area, with higher muscle $\mathrm{Hg}$ concentrations found in individuals from Reunion Island relative to those captured in the Mozambique Channel for similarsized individuals (Kojadinovic et al., 2006, 2007). Yellowfin tunas from Reunion Island also showed slightly higher $\mathrm{Cu}$ and $\mathrm{Zn}$ muscle concentrations relative to those captured southern in the Mozambique Channel, while concentrations in Cd were similar. Kojadinovic et al. (2007) then linked the spatial differences observed to the main prey consumed by tunas in the different zones. Indeed, in the case of $\mathrm{Hg}$, mesopelagic prey species were found to present enhanced $\mathrm{Hg}$ bioaccumulation in various ecosystems, in comparison to epipelagic species (Monteiro et al., 1996; Choy et al., 2009; Chouvelon et al., 2012b). Moreover, most fish and piscivorous species mainly accumulate Hg under its organic form methyl-Hg (Bloom, 1992; Cossa et al., 2012), which is the most stable form, the most bioavailable and thus the most bioaccumulable form of $\mathrm{Hg}$ by organisms (Fitzgerald et al., 2007). The proportion of methyl-Hg relative to total-Hg in other types of organisms and prey (e.g., crustaceans, cephalopod molluscs, bivalve molluscs, or lower trophic level organisms in general) was shown to be less important and/or more variable (e.g., Claisse et al., 2001; Bustamante et al., 2006; Cossa et al., 2012). As a consequence, piscivorous predators may be more exposed to $\mathrm{Hg}$ than predators feeding on other prey types. A recent study reported a positive correlation between the frequency of occurrence of fish prey in the diet of dolphinfish, tunas and sharks, and the mean $\mathrm{Hg}$ concentrations measured in the muscle of these predators (Teffer et al., 2014). The diet and feeding habits of tunas from the present study indicated a higher consumption of fish prey (reconstituted prey weight) for individuals captured in SEY (i.e. relative to those from REU and SA; Nikolic et al., 2015; M. Potier and N. Bodin, personal communication). The mean size of prey (notably fish prey) was also found to be larger (i.e. prey of potentially higher trophic level) for individuals from REU and SEY than those from SA. Lastly, juvenile tunas were reported to be gregarious and found more in surface than adult tunas, the latter presenting more individual behaviours and being generally found deeper (e.g., Domokos et al., 2007, Cosgrove et al., 2014; reviewed in Nikolic et al., 2016), potentially feeding more on deeper prey species presenting higher $\mathrm{Hg}$ burdens. All this information may therefore explain the order of concentrations found for $\mathrm{Hg}$, i.e. REU (fish diet important but not exclusive, prey size important and deeper behaviour reported by Nikolic et al., 2015) > SEY (almost exclusively fish diet and prey size important, but surface behaviour reported) $>>$ SA (fish diet important but not exclusive, lower prey 
size and surface behaviour reported). Furthermore, tunas from SA were shown to ingest greater proportions of both crustaceans and cephalopods relative to tunas from other areas, although cephalopod prey were also significant in terms of occurrence and reconstituted prey weight in the diet of REU tunas (Nikolic et al., 2015; M. Potier and N. Bodin, personal communication). This may account for the significantly higher $\mathrm{Cu}$ and $\mathrm{Cd}$ concentrations found in individuals from SA, regardless of the size of fish. Indeed, $\mathrm{Cu}$ is one constituent of crustaceans' respiratory pigment (hemocyanin), as it is the case for some molluscs such as cephalopods (Eisler, 2010). Crustacean and cephalopod prey therefore accumulate $\mathrm{Cu}$ in relatively high proportions in their tissues (e.g. Amiard et al., 1980; Miramand and Bentley, 1992; Eisler, 2010) and may contribute to the intake of $\mathrm{Cu}$ by their predators. Similarly, invertebrate prey species such as crustaceans or cephalopods exhibit higher $\mathrm{Cd}$ concentrations relative to fish (Amiard et al., 1980; Cossa and Lassus, 1989; Lahaye et al., 2005), and cephalopods (notably oceanic species) were proved to be a main vector of $\mathrm{Cd}$ for predators such as marine mammals (Caurant and Amiard-Triquet 1995; Bustamante et al., 1998; Lahaye et al., 2005).

Finally, in addition to seasonal and/or geographical differences in the trophic ecology of individuals to explain the tuna concentrations observed, potential differences i) in trace metal environmental (abiotic) concentrations, or ii) in the bioavailability of elements at the base of the different food webs exploited, may constitute supplemental factors leading to the observations made. For instance, REU and SEY beyond to the same biogeographic province (following Oliver and Irwin, 2008), are more oligotrophic areas compared with SA (Longhurst, 1998; Sherman and Hempel, 2008), and oligotrophic conditions in the Mediterranean Sea were supposed to enhance the bioavailability of $\mathrm{Hg}$ (through methylation by bacteria) (Heimbürger et al., 2010). This may also contribute to the higher $\mathrm{Hg}$ concentrations observed in REU and SEY tunas relative to SA. Determination of trace metal concentrations in water and low trophic level organisms (i.e. plankton) would enable testing of this hypothesis, especially as abiotic and low trophic level chemical composition would directly affect the concentrations that can be found in the different prey species consumed in the different areas, and in predators. Indeed, in the case of $\mathrm{Cr}$ for instance, higher inputs and environmental concentrations in SA marine waters may be expected, because SA has been recognized for a long time and at the worldwide level a major reservoir for chromite mining (i.e. main ore from which industrially produced $\mathrm{Cr}$ comes from; Chiffoleau, 1994).

\subsection{Relationships with trophic markers and POP patterns}

The results obtained for the other potential tracers (stable isotope and POP tracers) were consistent with trace metals. As such, $\delta^{15} \mathrm{~N}$ values clearly segregated individuals captured in the WIO (REU and SEY) from those collected in SA. For $\delta^{13} \mathrm{C}$ values, the greater significance of seasonal/year differences than the geographic factor may be linked to shorter-term variations in $\mathrm{C}$ sources or baseline $\delta^{13} \mathrm{C}$ values (reflected in higher trophic levels) than for contaminants. Several factors, linked to the season, may effectively induce variations in $\delta^{13} \mathrm{C}$ values of particulate organic matter (POM) or of primary 
producers directly, including: i) temperature (influencing carbon isotopic fractionation in phytoplankton, e.g., Fontugne and Duplessy, 1981; Goericke and Fry, 1994; Rau et al., 1997); ii) partial pressure and molecular $\mathrm{CO}_{2}$ concentration in ambient waters (Rau et al., 1997); iii) phytoplankton cell size, cell surface area/volume or cell geometry (Popp et al., 1998); iv) POM and/or phytoplankton composition (Darnaude et al., 2004; Harmelin-Vivien et al., 2008), with diatoms presenting higher $\delta^{13} \mathrm{C}$ values than other phytoplankton groups such as dinoflagellates (Fry and Wainwright, 1991). Furthermore, the temporal integration of $\mathrm{C}$ and $\mathrm{N}$ stables isotopes in biological tissues may differ slightly from those of trace metals. Animals can exhibit variable integration time of $\mathrm{C}$ and N signals from their food during tissue biosynthesis (Martínez del Rio et al., 2009), depending on species or on individual physiology. For trace metals, several factors can also affect the muscle bioaccumulation of contaminants observed in situ by organisms (Luoma and Rainbow, 2005), depending for instance on organisms' regulation mechanisms for the different contaminants. Trace metal concentrations in the muscle are generally thought to be less variable and/or reflect metal exposure on the relatively long term, i.e. order of several weeks or months, in comparison with tissues such as liver or kidneys that probably reflect contamination more immediately following contaminant incorporation, and/or metal storage at more variable temporal scales (i.e. detoxification organs, involving metallothionein proteins; Reinfelder et al., 1998; Wang and Rainbow, 2010). The muscle burden in some metals might thus reflect longer-term exposure than the seasonal scale, for instance. However, estimating metal kinetics (both accumulation and elimination) in the tissues of in situ organisms remains very complex. Indeed, experimental studies have shown that in fish for instance, it strongly depends on species, on metals, and on their potential interactions, on the exposure dose and on the exposure pathway (dissolved vs. trophic), etc. Moreover, experimental studies are generally performed on small species and/or juvenile individuals, on a single species at time or during relatively short periods of time, and sometimes results are contradictory (e.g., Kargin and Çoǵun, 1999; Kim et al., 2004; Kraemer et al., 2005; Łuszczek-Trojnar et al., 2013). This makes very difficult to extrapolate to top predators or long-lived species such as the tunas analysed here.

598 Despite these potential artefacts, trophic markers and more specifically $\delta^{15} \mathrm{~N}$ values provided supplemental evidence that great spatial variations occur in $\delta^{15} \mathrm{~N}$ values at the base of different food webs (along with $\delta^{13} \mathrm{C}$ values), and that $\delta^{15} \mathrm{~N}$ cannot be used independently as a proxy of the trophic positions of organisms unless the data are compared within a given environment (Jennings and Warr 2003; Ménard et al., 2007; Chouvelon et al., 2012a; Pethybridge et al., 2015). Moreover, $\delta^{15} \mathrm{~N}$ values measured in consumers may indicate different trophic functioning at the base of food webs (e.g., oligotrophy vs. mesotrophy; low vs. high primary production; etc.). As for $\delta^{13} \mathrm{C}$ values, differences in baseline $\delta^{15} \mathrm{~N}$ values occur naturally (Montoya, 2007). They are intimately linked to 606 processes occurring at the dissolved inorganic nitrogen (DIN) level, or to POM and/or phytoplankton composition, which reflect in higher trophic levels. Some of these processes lead to higher $\delta^{15} \mathrm{~N}$ values, including: i) when DIN demand is higher than the supply of nutrients in a particular area (i.e. 
high primary production/bloom events), primary producers may be faced with a ${ }^{15} \mathrm{~N}$-enriched $\mathrm{N}$ source

610 (e.g., "recycled" or ammonium-enriched, especially if it comes from higher trophic levels), which is

611 then reflected in the local food chain (Montoya, 2007); ii) when most of the organic matter is dissolved

612 in particular environments, microbial food webs are predominantly supported (Biddanda et al., 2001)

613 and microbial processing or remineralization of organic matter at the base of food webs usually results

614 in higher $\delta^{15} \mathrm{~N}$ values (Jennings and Warr, 2003; MacKenzie et al., 2014). Alternatively, other

615 processes can lead to lower $\delta^{15} \mathrm{~N}$ values measured, including the fixation of atmospheric $\mathrm{N}_{2}$ by

616 diazotrophic organisms (e.g., cyanobacteria) in offshore or oligotrophic waters, which lower the $\delta^{15} \mathrm{~N}$

617 values of the residual $\mathrm{NO}_{3}^{-}$pool available for primary producers in these areas (Montoya, 2007) and

618 result in low $\delta^{15} \mathrm{~N}$ values in consumers. As such, SIA results of the present study highlighted the

619 higher primary productivity in SA waters (i.e. higher $\delta^{15} \mathrm{~N}$ values measured in tunas from this

620 ecosystem subject to the Benguela and Agulhas currents), while REU and SEY, located in the Indian

621 South Subtropical Gyre province, face more oligotrophic conditions (i.e. lower $\delta^{15} \mathrm{~N}$ values measured

622 in tunas from these areas) (Longhurst, 1998; Oliver and Irwin, 2008; Sherman and Hempel, 2008).

623 Therefore, in addition to complement the information given by trace metals (i.e. segregation between

624 the different groups of tunas), SIA in tuna muscle appeared powerful in providing information on local

625 biogeochemistry ( $\mathrm{C}$ and $\mathrm{N}$ sources), including trophic functioning at the base of food webs. Recently

626 in the southwest Pacific Ocean, Pethybridge et al. (2015) similarly reported a latitudinal gradient of

$627 \delta^{15} \mathrm{~N}$ values in albacore tuna, and linked this gradient to nutrient cycling dynamics and oceanographic

628 features in both oceans (i.e. lower $\delta^{15} \mathrm{~N}$ values in environments with more oligotrophic conditions).

629 The POP patterns further supported the spatial segregation of tunas between REU and SA (i.e.

630 between the WIO and the SEAO). Higher PCB and DDT concentrations in tunas from SA in

631 comparison with REU were previously reported by Munschy et al. (2016), and were attributed to

632 higher dietary inputs and higher total lipid content in SA. In the present study, the POP tracers also

633 provided complementary information on potential differences in the sources of contamination across

634 the different areas. For instance, the "o,p'-DDT/p,p'-DDT" ratio (commonly used to determine the

635 DTT origins) showed significant different mean values (0.30 in REU vs. 0.17 in SA, Table 4),

636 although both were close to those characterising the technical mixture (0.2-0.3, Kalantzi et al., 2001).

637 Similarly, a significant difference in the " $p, p^{\prime}$-DDT/ $p, p^{\prime}$-DDE" ratio was found between individuals

638 from these two areas. This ratio is generally used to trace the resident time and degree of degradation

639 of $p, p^{\prime}$-DDT (Suárez et al., 2013). Despite the differences observed, the values of this ratio (i.e. $<0.5$ )

640 indicate old DDT inputs in both areas (Suárez et al., 2013). Alternatively, the "Sum DDTs/Sum PCBs"

641 ratio, used to distinguish the influence of sources from agricultural origin (when $>1$ ) vs. sources from

642 industrial origin (Lailson-Brito et al., 2011), exhibited high values in both areas. Therefore, it

643 highlighted the important agricultural use of DDT (in comparison with industrial sources) in the

644 southern hemisphere, including both REU and SA, while DDT has been banned for several years or

645 even decades in northern countries. 


\subsection{Conclusions and further work perspectives}

647 Our results demonstrated that inorganic elements, when considered in isolation, are quite efficient in 648 discriminating individuals from different geographic origins. However, the coupling with trophic 649 markers (SIA) and with information derived from stomach contents analysis (e.g., Nikolic et al., 2015) 650 appeared essential for explaining the metal contamination profiles observed, and for distinguishing 651 more clearly the different populations exploiting different food webs. Information derived from POP 652 analyses were also very complementary, including the ratios used in the present study and the detailed 653 contamination results reported previously by Munschy et al. (2016). It strengthened the metal results 654 by supporting the spatial segregation of tunas observed between the WIO and the SEAO as well, by 655 evidencing the influence of the trophic ecology on the contamination observed (i.e. different food 656 webs exploited by the tuna populations), and it also provided substantial information on the potential sources of contamination (i.e. agricultural vs. industrial sources) in the study areas. When using and interpreting biogeochemical tracers, since different prey compositions in the diet can lead to similar isotopic signatures or contaminant concentrations in a predator's tissues (e.g. Bearhop et al., 2004), one must effectively keep in mind that only differences are really informative.

661 The investigation of metal isotope ratios would be useful to understand the origin and the sources of 662 metal contamination (e.g., $\mathrm{Cu}$ or Hg isotopes; El Azzi et al., 2013; Perrot et al., 2010). Other 663 interesting perspectives would include further work on environmental matrices (e.g., speciation of 664 metals in the water) and on lower trophic level organisms in the different areas, to thoroughly understand the processes of metal transfer leading to the differences observed in top predators. Additionally, apprehending the mechanisms of metal regulation by the different fish populations, through the analysis of metallothioneins in detoxification organs and/or through the analysis of genetic markers of metallothioneins, would also be of interest. Finally, the analysis of emerging contaminants could help to define more comprehensive or exhaustive chemical contamination profiles, although this study demonstrated that classically and historically monitored contaminants are already very informative.

672 Our results are also important in a fisheries management perspective, through the assessment of the potential links (gene flows, individuals migrations, etc.) between Atlantic and Indian Oceans stocks, managed by different Regional Fisheries Management Organisations. Indeed, one of the key issues to improve the management of albacore tuna is a better understanding of the spatial dynamics and population connectivity. At the integration time scale represented by this study of metal bioaccumulation and additional trophic and chemical tracers in tuna muscle, the differences observed suggested limited flows of individuals between the SEAO and the WIO. In the near future, further coupling of this information derived from chemical/ecological tracers with genetic data should help refine management units and stocks of albacore tunas in the southern hemisphere, and more specifically in the Indian and Atlantic Oceans. 


\section{Acknowledgments}

684

685

686

687

688

689

690

691

692

693

694

695

696

697

698

699

700

701

702

703

704

705

706

707

708

709

710

711

712

713

714

This work was conducted in the framework of the GERMON project "N759/DMSOI/2013" funded by the European Fisheries Funds EU FEP 2013-2015 and IFREMER. JB and NN were head and scientific leader of the project, respectively. The authors want to thank all partners from the GERMON project for their implication in the collection, dissection and preparation of the fish samples: Melissa Meyer, Janine Cunningham and Kenneth Baloyi (DAFF); Chris Heinecken (CAPFISH); Louw Hoffman (Stellenbosch University); Sean Walker (Breakwater Products); Evgeny Romanov, Emilie Richard and Loïc Le Foulgoc (CAPRUN - HYDRO REUNION); Emmanuel Jouen (CIRAD); Jean Turquet (ARVAM); Emilie Augustin, Alex Tirant, Jimy Esparon, Emmanuel Chassot, Alain Damiano and Cindy Assan (IRD/SFA); François Rossi, Gary Algae, Patricia and Francis (Indian Ocean Tuna Ltd); the fishermen from the longliner MANOHAL and REUNIPECHE; the firm IEMANJA that operated the longliners; Laurence Maurel (Kart'Eau) for her help on QGIS and ArcGIS; the staff from the IFREMER/BE/LBCO laboratory for POP analyses (Karine Héas-Moisan, Nathalie Olivier, Nadège Bely, Charles Pollono); and finally, all the staff from IFREMER Délégation Océan Indien (notably Franck Bruchon, Magali Duval, David Roos, Hugues Evano, Ludovic Hoarau, Yoann Aumond, Edouard Collin).

\section{References}

Amiard JC, Amiard-Triquet C, Metayer C, Marchand J (1980) Etude du transfert de Cd, Pb, Cu et Zn dans les chaînes trophiques néritiques et estuariennes - I. Etat dans l'estuaire interne de la Loire (France) au cours de l'été 1978. Water Res 14: 665-673

Arrizabalaga H, Costas E, Juste J, González-Garcás A, Nieto B, López-Rodas V (2004) Population structure of albacore Thunnus alalunga inferred from blood groups and tag-recapture analyses. Mar Ecol Prog Ser 282: 245-252

Bearhop S, Adams CE, Waldron S, Fuller RA, MacLeod H (2004) Determining trophic niche width: a novel approach using stable isotope analysis. J Animal Ecol 73: 1007-1012

Biddanda B, Ogdahl M, Cotner J (2001) Dominance of bacterial metabolism in oligotrophic relative to eutrophic waters. Limnol Oceanogr 46: 730-739

Bloom NS (1992) On the chemical form of mercury in edible fish and marine invertebrate tissue. Can J Fish Aquat Sci 49: 1010-1017

Bodiguel X, Loizeau V, Le Guellec AM, Roupsard F, Philippon X, Mellon-Duval C (2009) Influence of sex, maturity and reproduction on PCB and p,p'DDE concentrations and repartitions in the 
European hake (Merluccius merluccius, L.) from the Gulf of Lions (N.W. Mediterranean). Sci Total Environ 408: 304-311

Bodin N, Budzinski H, Le Ménach K, Tapie N (2009) ASE extraction method for simultaneous carbon and nitrogen stable isotope analysis in soft tissues of aquatic organisms. Anal Chim Acta 643: 5460

Bodin N, Lesperance D, Albert R, Hollanda S, Degroote M, Churlaud C, Bustamante P (2017) Trace elements in oceanic pelagic communities in the western Indian Ocean. Chemosphere 174: 354362

Bogdal C, Abad E, Abalos M, van Bavel B, Hagberg J, Sheringer M, Fieldler H (2013) Worldwide distribution of persistent organic pollutants in air, including results of air monitoring by passive air sampling in five continents. TRAC-Trend Anal Chem 46: 150-161

Bourjea J, Lapègue S, Gagnevin L, Broderick D, Mortimer JA, Ciccione S, Roos D, Taquet C, Grizel H (2007) Phylogeography of the green turtle, Chelonia mydas in the Southwest Indian Ocean. Mol Ecol 16: 175-186

Briggs JC (1974) Marine Zoogeography. McGraw-Hill series in Population Biology, McGraw- Hill, New York

Bustamante P, Caurant F, Fowler SW, Miramand P (1998) Cephalopods as a vector for the transfer of cadmium to top marine predators in the north-east Atlantic Ocean. Sci Total Environ 220: 71-80

Bustamante P, Lahaye V, Durnez C, Churlaud C, Caurant F (2006) Total and organic Hg concentrations in cephalopods from the North Eastern Atlantic waters: influence of geographical origin and feeding ecology. Sci Total Environ 368: 585-596

Caurant F, Amiard-Triquet C (1995) Cadmium contamination in pilot whales Globicephala melas: source and potential hazard to the species. Mar Pollut Bull 30: 207-210

Chen C, Amirbahman A, Fisher N, Harding G, Lamborg C, Nacci D, Taylor D (2008) Methylmercury in marine ecosytems: Spatial patterns and processes of production, bioaccumulation, and biomagnification. EcoHealth 5: 399-408

Chen CY, Lai CC, Chen KS, Hsu CC, Hung CC, Chen MH (2014) Total and organic mercury concentrations in the muscles of Pacific albacore (Thunnus alalunga) and bigeye tuna (Thunnus obesus). Mar Pollut Bull 85: 606-612

Chen IC, Lee PF, Tzeng WN (2005) Distribution of albacore (Thunnus alalunga) in the Indian Ocean and its relation to environmental factors. Fish Oceanogr 14: 71-80

Cheung MS, Wang WS (2008) Analyzing biomagnification of metals in different marine food webs using nitrogen isotopes. Mar Pollut Bull 56: 2082-2105

Chiffoleau JFC (1994) Le chrome en milieu marin. Rapports Scientifiques et Techniques de l'IFREMER 8, Issy-les-Moulineaux, France, $111 \mathrm{pp}$.

Chouvelon T, Spitz J, Caurant F, Mèndez-Fernandez P, Chappuis A, Laugier F, Le Goff E, Bustamante P (2012a) Revisiting the use of $\delta^{15} \mathrm{~N}$ in meso-scale studies of marine food webs by 
considering spatio-temporal variations in stable isotopic signatures - the case of an open ecosystem: the Bay of Biscay (North-East Atlantic). Prog Oceanogr 101: 92-105

Chouvelon T, Spitz J, Caurant F, Mèndez-Fernandez P, Autier J, Lassus-Débat A, Bustamante P (2012b) Enhanced bioaccumulation of mercury in deep-sea fauna from the Bay of Biscay (NorthEast Atlantic) in relation to trophic positions identified by analysis of carbon and nitrogen stable isotopes. Deep-Sea Res I 65: 113-124

Chouvelon T, Caurant F, Cherel Y, Spitz J, Simon-Bouhet B, Bustamante P (2014) Species- and sizerelated patterns in stable isotopes and mercury concentrations in fish help refine marine ecosystem indicators and provide evidence for distinct management units for hake in the Northeast Atlantic. ICES J Mar Sci 75: 1073-1087

Choy CA, Popp BN, Kaneko JJ, Drazen JC (2009) The influence of depth on mercury levels in pelagic fishes and their prey. P Natl Acad Sci USA 106: 13865-13869

Claisse D, Cossa D, Bretaudeau-Sanjuan J, Touchard G, Bombled B (2001) Methylmercury in molluscs along the French Coast. Mar Pollut Bull 42: 329-332

Cosgrove R, Arregui I, Arrizabalaga H, Goñi N, Sheridan M (2014) New insights to behaviour of North Atlantic albacore tuna (Thunnus alalunga) observed with pop-up satellite archival tags. Fish Res 150: 89-99

Cossa D, Harmelin-Vivien M, Mellon-Duval C, Loizeau V, Averty B, Crochet S, Chou L, Cadiou JF (2012) Influences of bioavailability, trophic position, and growth on methylmercury in hakes (Merluccius merluccius) from Northwestern Mediterranean and Northeastern Atlantic. Environ Sci Tech 46: 4885-4893

Cossa D, Lassus P (1989) Le cadmium en milieu marin. Biogéochimie et écotoxicologie. Rapports Scientifiques et Techniques de l'IFREMER 16, Issy-les-Moulineaux, France, 111 pp.

Cresson P, Bouchoucha M, Morat F, Miralles F, Chavanon F, Loizeau V, Cossa D (2015) A multitracer approach to assess the spatial contamination pattern of hake (Merluccius merluccius) in the French Mediterranean. Sci Tot Environ 532: 184-194

Croteau MN, Luoma SN, Stewart AR (2005) Trophic transfer of metals along freshwater food webs: evidence of cadmium biomagnification in nature. Limnol Oceanogr 50: 1511-1519

Darnaude AM, Salen-Picard C, Harmelin-Vivien ML (2004) Depth variation in terrestrial particulate organic matter exploitation by marine coastal benthic communities off the Rhone River delta (NW Mediterranean). Mar Ecol Prog Ser 275: 47-57

Das K, Lepoint G, Loizeau V, Debacker V, Dauby P, Bouquegneau JM (2000) Tuna and dolphin associations in the North-east Atlantic: Evidence of different ecological niches from stable isotope and heavy metal measurements. Mar pollut Bull 40: 102-109

Domokos R, Seki MP, Polovina JJ, Hawn DR (2007) Oceanographic investigation of the American Samoa albacore (Thunnus alalunga) habitat and longline fishing grounds. Fish Oceanogr 16: 555572. 
Duncan KM, Martin AP, Bowen BW, de Couet HG (2006) Global phylogeography of the scalloped hammerhead shark (Sphyrna lewini) Mol Ecol 15: 22-39.

Durand JD, Collet A, Chow S, Guinand B, Borsa P (2005) Nuclear and mitochondrial DNA markers indicate unidirectional gene flow of Indo-Pacific to Atlantic bigeye tuna (Thunnus obesus) populations, and their admixture off southern Africa. Mar Biol 147: 313-322

Dhurmeea Z, Zudaire I, Chassot E, Cedras M, Nikolic N, Bourjea J, West W, Appadoo C, Bodin N (2016) Reproductive Biology of Albacore Tuna (Thunnus alalunga) in the Western Indian Ocean. PloS ONE 11(12): e0168605. doi:10.1371/journal.pone.0168605

Eisler R (2010) Compendium of trace metals and marine biota. Volume 1: Plants and Invertebrates. Elsevier Publishing, $610 \mathrm{p}$.

El Azzi D, Viers J, Guiresse M, Probst A, Aubert D, Caparros J, Charles F, Guizien K, Probst JL (2013) Origin and fate of copper in a small Mediterranean vineyard catchment: New insights from combined chemical extraction and $\delta^{65} \mathrm{Cu}$ isotopic composition. Sci Tot Environ 463-464: 91-101

European Commission (2006) No 1881/2006 of 19 December 2006 setting maximum levels for certain contaminants in foodstuffs (text with EEA relevance)

FAO (2016) The State of World Fisheries and Aquaculture 2016. FAO, Rome, Italy.

Fisk AT, Hobson KA, Norstrom RJ (2001) Influence of chemical and biological factors on trophic transfer of Persistent Organic Pollutants in the Northwater Polynya marine food web. Envrion Sci Tech 35: 732-738

Fisk AT, Tittlemier SA, Pranschke JL, Norstrom RJ (2002) Using anthropogenic contaminants and stable isotopes to assess the feeding ecology of Greenland shark. Ecology 83: 2162-2172

Fitzgerald WF, Lamborg CH, Hammerschmidt CR (2007) Marine biogeochemical cycling of mercury. Chem Rev 107: 641-662

Fontugne MR, Duplessy JC (1981) Organic carbon isotopic fractionation by marine plankton in the temperature range -1 to $31^{\circ} \mathrm{C}$. Oceanol Acta 4: $85-90$

France RL (1995) Carbon-13 enrichment in benthic compared to planktonic algae: food web implications. Mar Ecol Prog Ser 124: 307-312

Fry B, Wainwright SC (199). Diatom sources of C-rich carbon in marine food webs. Mar Ecol Prog Ser 76: $149-157$

Goericke R, Fry B (1994) Variations of marine plankton $\delta^{13} \mathrm{C}$ with latitude, temperature, and dissolved $\mathrm{CO}_{2}$ in the world ocean. Global Biogeoch Cycles 8: 85-90

Gray JS (2002) Biomagnification in marine systems: the perspective of an ecologist. Mar Pollut Bull 45: $46-52$

Guan W, Tang L, Zhu J, Tian S, Xu L (2016) Application of a Bayesian method to data-poor stock assessment by using Indian Ocean albacore (Thunnus alalunga) stock assessment as an example. Acta Oceanol Sin 35: 117-125 
Harmelin-Vivien M, Loizeau V, Mellon C, Beker B, Arlhac D, Bodiguel X, Ferraton F, Hermand R, Philippon X, Salen-Picard C (2008) Comparison of C and N stable isotope ratios between surface particulate organic matter and microphytoplankton in the Gulf of Lions (NW Mediterranean). Cont Shelf Res 28: 1911-1919

Heimbürger LE, Cossa D, Marty JC, Migon C, Averty B, Dufour A, Ras J (2010) Methyl mercury distributions in relation to the presence of nano and picophytoplankton in an oceanic water column (Ligurian Sea, North-western Mediterranean). Geochim Cosmchim Acta 74: 5549-5559

Hisamichi Y, Haraguchi K, Endo T (2010) Levels of mercury and organochlorine compounds and stable isotope ratios in three tuna species taken from different regions of Japan. Environ Sci Tech 44: $5971-5978$

Hobson KA (1999) Tracing origins and migration of wildlife using stable isotopes: a review. Oecologia 120: 314-326

Iverson SJ, Field C, Bowen WD, Blanchard W (2004) Quantitative fatty acid signature analysis: a new method of estimating predator diets. Ecol Monogr 74: 211-235

ICCAT (2016) Report of the 2016 ICCAT North and South Atlantic albacore stock assessment meeting, International Commission for the Conservation of Atlantic Tunas, Madeira, Portugal

IOTC (2016) Report of the sixth Session of the IOTC working party on temperate tunas. IOTC-2016WPTmT06-R[E]. , Indian Ocean Tuna Commission, Shanghai, China

Jennings S, Warr KJ (2003) Environmental correlates of large-scale spatial variation in the $\delta^{15} \mathrm{~N}$ of marine animals. Mar Biol $142: 1131-1140$

Jones KC, de Voogt P (1999) Persistent organic pollutants (POPs): state of the science. Environ Pollut 100: 209-221

Juan-Jordá MJ, Mosqueira I, Freire J, Ferrer-Jordá E, Dulvy NK (2016) Global scombrid life history dataset. Ecology 97: 809.

Kalantzi OI, Alcock RE, Johnston PA, Santillo D, Stringer RL, Thomas GO, Jones KC (2001) The global distribution of organochlorine pesticides in butter. Environ Sci Technol 35 : 1013-1018

Karazulak FS, Özgür E, Gökoglu M, Emecan IT, Baskaya A (2011) Age and growth of albacore (Thunnus alalunga Bonnaterre, 1788) from the eastern Mediterranean. Turk J Zool 35: 801-810

Kargin F, Çoǵun HY (1999) Metal interactions during accumulation and elimination of zinc and cadmium in tissues of the freshwater fish Tilapia nilotica. Bull Environ Contam Toxicol 62: 511519

Kelly JF (2000) Stable isotopes of carbon and nitrogen in the study of avian and mammalian trophic ecology. Can J Zool 78: 1-27

Kim SG, Jee JH, Kang JC (2004) Cadmium accumulation and elimination in tissues of juvenile olive flounder, Paralichthys olivaceus after sub-chronic cadmium exposure. Environ Pollut 127: 117123 
Kojadinovic J, Potier M, Le Corre M, Cosson RP, Bustamante B (2006) Mercury content in commercial pelagic fish and its risk assessment in the Western Indian Ocean. Sci Tot Environ 366: $688-700$

Kojadinovic J, Potier M, Le Corre M, Cosson RP, Bustamante B (2007) Bioaccumulation of trace elements in pelagic fish from the Western Indian Ocean. Environ Pollut 146: 548-566

Kraemer LD, Campbell PGC, Hare L (2005) A field study examining metal elimination kinetics in juvenile yellow perch (Perca flavescens). Aquat Toxicol 75: 108-126

Krahn MM, Herman DP, Matkin CO, Durban JW, Barrett-Lennard L, Burrows DG, Dahlheim ME, Black N, LeDuc RG, Wade PR (2007) Use of chemical tracers in assessing the diet and foraging regions of eastern North Pacific killer whales. Mar Environ Res 63: 91-114

Lahaye V, Bustamante P, Spitz J, Dabin W, Das K, Pierce GJ, Caurant F (2005) Long-term dietary segregation of short-beaked common dolphins (Delphinus delphis) in the Bay of Biscay determined using cadmium as an ecological tracer. Mar Ecol Prog Ser 305: 275-285

Lailson-Brito J, Dorneles PR, Azevedo-Silva CE, de Freitas Azevedo A, Gama Vidal L, Marigo J, Bertozzi C, Zanelatto RC, Lemos Bisi T, Malm O, Machado Torres JP (2011). Organochlorine concentrations in franciscana dolphins, Pontoporia blainvillei, from Brazilian waters. Chemosphere 84: 882-887.

Lewis AD (1990) South Pacific albacore stock structure: a review of available information. In: 3rd South Pacific albacore Research Workshop, Working Paper (5): 1-13. Nouméa, New Caledonia, South Pacific Commission.

Longhurst AR (1998) Ecological geography of the sea. Academic Press, San Diego, CA, USA, 398 p.

Luoma SN, Rainbow PS (2005) Why is metal bioaccumulation so variable? Biodynamics as a unifying concept. Environ Sci Tech 39: 1921-1931

Łuszczek-Trojnar E, Drag-Kozak E, Popek W (2013) Lead accumulation and elimination in tissues of Prussian carp, Carassius gibelio (Bloch, 1782), after long-term dietary exposure, and depuration periods. Envrion Sci Pollut Res 20: 3122-3132

MacKenzie KM, Longmore C, Preece C, Lucas CH, Trueman CN (2014) Testing the long-term stability of marine isoscapes in shelf seas using jellyfish tissues. Biogeochemistry $121: 441-454$

Martínez del Rio C, Wolf N, Carleton SA, Gannes LZ (2009) Isotopic ecology ten years after a call for more laboratory experiments. Biol Rev Cambridge Philosophical Society 84 : 91-111

Mason RP (2013) Trce metals in aquatic systems. Blackwell Publishing Ltd, 431 p.

Mathews T, Fisher NS (2009) Dominance of dietary intake of metals in marine elasmobranch and teleost fish. Science of the Total Environment 407: 5156-5161

Ménard F, Lorrain A, Potier M, Marsac F (2007) Isotopic evidence of distinct feeding ecologies and movement patterns in two migratory predators (yellowfin tuna and swordfish) of the western Indian Ocean. Mar Biol 153: 141-152 
Mèndez-Fernandez P, Pierce GJ, Bustamante P, Chouvelon T, Ferreira M, González AF, López A, Read F, Santos MB, Spitz J, Vingada JV, Caurant F (2013) Ecological niche segregation among five toothed whale species off the NW Iberian Peninsula using ecological tracers as multiapproach. Marine Biology 160: 2825-2840

Méndez-Fernandez P, Simon-Bouhet B, Bustamante P, Chouvelon T, Ferreira M, López A, Moffat C, Pierce GJ, Russell M, Santos MB, Spitz J, Vingada JV, Webster L, Read F, González A, Caurant F (2017) Inter-species differences in polychlorinated biphenyls patterns from five sympatric species of odontocetes: can PCBs be used as tracers of feeding ecology? Ecol Indic 74: 98-108

Miramand P, Bentley D (1992) Concentration and distribution of heavy metals in tissues of two cephalopods, Eledone cirrhosa and Sepia officinalis, from the French coast of the English Channel. Mar Biol 114: 407-414

Monteiro LR, Costa V, Furness RW, Santos RS (1996) Mercury concentrations in prey fish indicate enhanced bioaccumulation in mesopelagic environments. Mar Ecol Prog Ser 141: 21-25

Montoya JP (2007) Natural abundance of ${ }^{15} \mathrm{~N}$ in marine planktonic ecosystems. In: Michener, R, Lajtha K (Eds), Stable Isotopes in Ecology and Environmental Science. Blackwell Publishing, pp. 76-201

Munschy C, Bodin N, Potier M, Héas-Moisan K, Pollono C, Degroote M, West W, Hollanda SJ, Puech A, Bourjea A, Nikolic N (2016) Persitant Organic Pollutants in albacore tuna (Thunnus alalunga) from Reunion Island (Southwest Indian Ocean) and South Africa in relation to biological and trophic characteristics. Environ Res 148: 196-206

Nakamura H (1969) Tuna distribution and migration. Fishing News Ltd, London.

Neff JM (2002) Bioaccumulation in marine organisms. Effect of contaminants from oil well produced water. Elsevier Ltd, 452 pp.

Newsome SD, Clementz MT, Koch PL (2010) Using stable isotope biogeochemistry to study marine mammal ecology. Mar Mam Sci 26: 509-572

Nikolic N, Morandeau G, Hoarau L, West W, Arrizabalaga H, Hoyle S, Nicol SJ, Bourjea J, Puech A, Farley JH, Williams AJ, Fonteneau A (2016) Review of albacore tuna, Thunnus alalunga, biology, fisheries and management. Rev Fish Biol Fisheries. DOI : 10.1007/s11160-016-9453-y

Nikolic N, Puech A, Chouvelon T, Munschy C, Bodin N, Brach-Papa C, Potier M, West W, Knoery J, Zudaire I, Dhurmeea Z, Degroote M, Cedras M, Evano H, Bourjea J (2015) GERMON project final report (GEnetic stRucture and Migration Of albacore tuna). IFREMER report RST/DOI/2015-09, 219 pp.

Oliver MJ and Irwin AJ (2008) Objective global ocean biogeographic provinces. Geophys res Lett 35: L15601

Perrot V, Epov VN, Pastukhov MV, Grebenshchikova VI, Zouiten C, Sonke JE, Husted S, Donard OFX, Amouroux D (2010) Tracing sources and bioaccumulation of mercury in fish of Lake Baikal - Angara River using Hg isotopic composition. Environ Sci Tech 44: 8030-8037 
Pethybridge HR, Young JW, Kuhnert PM, Farley JH (2015) Using stable isotopes of albacore tuna and predictive models to characterize bioregions and examine ecological change in the SW Pacific Ocean. Prog Oceanogr 134: 293-303

Pierce GJ, Stowasser G, Hastie LC, Bustamante P (2008) Geographic, seasonal and ontogenetic variation in cadmium and mercury concentrations in squid (Cephalopoda: Teuthoidea) from UK waters. Ecotoxicol Environ Saf 70: 422-432

Popp BN, Laws EA, Bidigare RR, Dore JE, Hanson KL, Wakeham SG (1998) Effect of phytoplankton cell geometry on carbon isotopic fractionation. Geochim Cosmochim Acta 62: 69-77

Post DM (2002) Using stable isotopes to estimate trophic position: models, methods and assumptions. Ecology 83: 703-718

Pulster EL, Smalling KL, Maruya KA (2005) Polychlorinated biphenyls and toxaphene in preferred prey fish of coastal southeastern U.S. bottlenose dolphins (Tursiops truncatus). Environ Toxicol Chem 24: 3128-3136.

R Development Core Team (2012) R: a language and environment for statistical computing. R Foundation for Statistical Computing, Vienna, www.R-project.org

Rainbow PS (2002) Trace metal concentrations in aquatic invertebrates: why and so what? Environ Pollut 120: 497-507

Ramos R, González-Solís J (2012) Trace me if you can: the use of intrinsic biogeochemical markers in marine top predators. Front Ecol Environ 10:258-266

Ramos R, Ramírez F, Jover L (2013) Trophodynamics of inorganic pollutants in a wide-range feeder: The relevance of dietary inputs and biomagnification in the Yellow-legged gull (Larus michahellis). Environ Pollut 172: 235-242

Rau GH, Riebesell U, Wolf-Gladrow D (1997) $\mathrm{CO}_{2}$ aq-dependent photosynthetic ${ }^{13} \mathrm{C}$ fractionation in the ocean: A model versus measurements. Global Biogeoch Cycles 11: 267-278

Reinfelder JR, Fisher NS, Luoma SN, Nichols JW, Wang WX (1998) Trace element trophic transfer in aquatic organisms: a critique of the kinetic model approach. Sci Total Environ 219: 117-135

Ruelas-Inzunza J, Soto-Jiménez MF, Ruiz-Fernández AC, Ramos-Osuna M, Mones-Saucedo J, PáezOsuna $\mathrm{F}(2014){ }^{210} \mathrm{Po}, \mathrm{Cd}$ and $\mathrm{Pb}$ distribution and biomagnification in the yellowfin tuna Thunnus albacares and skipjack tuna Katsuwonus pelamis from the Eastern Pacific. Mar Pollut Bull 87: 98-103

Sardenne F, Bodin N, Chassot E, Amiel A, Fouché E, Degroote M, Debrauwer L, Guillou H, Lebreton B, Guillou G, Hollanda S, Menard F (2016) Trophic niches of sympatric tropical tuna in the western Indian Ocean inferred by stable isotopes and neutral fatty acids. Prog Oceanogr 146: 75 88

Sherman K, Hempel G (2008) The UNEP Large Marine Ecosystem report: A perspective on changing conditions in LMEs of the world's Regional Seas. UNEP Regional Seas Report and Studies No. 182. United Nations Environment Programme. Nairobi, Kenya. 
Sherwood GD, Rose GA (2005) Stable isotope analysis of some representative fish and invertebrates of the Newfoundland and Labrador continental shelf food web. Estuar Coast Shelf S 63: 537-549

Storelli MM, Giacominelli-Stuffler R, Marcotrigiano GO (2002) Total and methylmercury residues in tuna-fish from the Mediterranean Sea. Food Addit Contam 19: 715-720.

Storelli MM, Giacominelli-Stuffler R, Storelli A, Marcotrigiano GO (2005) Accumulation of mercury, cadmium, lead and arsenic in swordfish and bluefin tuna from the Mediterranean Sea: A comparative study. Mar pollut Bull 50: 993-1018

Suárez P, Ruiz Y, Alonso A, San Juan F (2013) Organochlorine compounds in mussels cultured in the Ría of Vigo: accumulation and origin. Chemosphere 90: 7-19

Teffer AK, Staudinger MD, Taylor DL, Juanes F (2014) Trophic influences on mercury accumulation in top pelgaic predators from offshore New England waters of the northwest Atlantic Ocean. Mar Environ Res 101: 124-134

Verreault J, Verboven N, aGabrielsen GW, Letcher RJ, Chastel O (2008) Changes in prolactin in a highly organohalogen contaminated Arctic top predator seabird, the glaucous gull. Gen Comp Endocr 156: 569-576

Wang WX (2002) Interactions of trace metals and different marine food chains. Mar Ecol Prog Ser 243: $295-309$

Wang WX, Rainbow PS (2010) Significance of metallothioneins in metal accumulation kinetics in marine animals. Comp Biochem Phys C 152: 1-8

Wang WX, Wong RSK (2003) Bioaccumulation kinetics and exposure pathways of inorganic mercury and methylmercury in a marine fish, the sweetlips Plectorhinchus gibbosus. Mar Ecol Prog Ser 257: $257-268$

Yogui GT, Santos MCD, Montone RC (2003) Chlorinated pesticides and polychlorinated biphenyls in marine tucuxi dolphins (Sotalia fluviatilis) from the Cananeia estuary, southeastern Brazil. Sci Total Environ 312: 67-78

Zuur AF, Ieno EN, Smith GM (2007) Analysing Ecological Data. Springer, New York (USA)

Zuur AF (2012) A beginner's guide to Generalized Additive Models with R. Highland Statistics Ltd, Newburgh (UK) 
Table 1: Results obtained for the certified reference materials (CRMs) used for trace metal analyses. Values are means \pm standard deviation, in mg.kg ${ }^{-1}$ dry mass $(\mathrm{dm})$. The number of replicates for each CRM was $37 \mathrm{for} \mathrm{Hg}$, and 18 for the other trace metals. Certified values are in italics. The recovery rate (in \%),

1002 the limit of quantification (LQ, in $\mathrm{mg} \cdot \mathrm{kg}^{-1} \mathrm{dm}$ ) and the percentage of individuals below the LQ (on the 443 analysed) are also indicated.

\begin{tabular}{|c|c|c|c|c|c|c|c|c|}
\hline $\begin{array}{l}\text { Trace } \\
\text { metal }\end{array}$ & $\begin{array}{l}\text { Certified } \\
\text { value }\end{array}$ & $\begin{array}{c}\text { Measured } \\
\text { value }\end{array}$ & $\begin{array}{l}\text { Recovery } \\
\text { rate }\end{array}$ & $\begin{array}{l}\text { Certified } \\
\text { value }\end{array}$ & $\begin{array}{c}\text { Measured } \\
\text { value }\end{array}$ & $\begin{array}{l}\text { Recovery } \\
\text { rate }\end{array}$ & LQ & $\begin{array}{c}\% \text { of } \\
\text { individuals } \\
<\text { LQ }\end{array}$ \\
\hline & & IAEA-407 & & & DOLT-3 & & & \\
\hline $\mathrm{Cr}$ & $0.73 \pm 0.06$ & $0.76 \pm 0.05$ & 104 & $3.5^{*}$ & $2.5 \pm 0.3$ & 71 & 0.03 & 0 \\
\hline $\mathbf{N i}$ & $0.60 \pm 0.05$ & $0.57 \pm 0.27$ & 95 & $2.72 \pm 0.35$ & $2.34 \pm 0.32$ & 86 & 0.03 & 81 \\
\hline $\mathrm{Cu}$ & $3.28 \pm 0.08$ & $3.00 \pm 0.07$ & 92 & $31.2 \pm 1.0$ & $30.8 \pm 0.6$ & 99 & 0.25 & 0 \\
\hline $\mathbf{Z n}$ & $67.1 \pm 0.8$ & $66.5 \pm 1.2$ & 99 & $86.6 \pm 2.4$ & $90.3 \pm 1.4$ & 104 & 2.5 & 0 \\
\hline Cd & $0.189 \pm 0.004$ & $0.179 \pm 0.009$ & 95 & $19.4 \pm 0.6$ & $19.2 \pm 0.3$ & 99 & 0.05 & 21 \\
\hline \multirow[t]{2}{*}{$\mathbf{P b}$} & $0.12 \pm 0.02$ & $0.11 \pm 0.03$ & 92 & $0.319 \pm 0.045$ & $0.377 \pm 0.191$ & 118 & 0.05 & 98 \\
\hline & & IAEA-142 & & & & & & \\
\hline $\mathrm{Hg}$ & $0.126 \pm 0.007$ & $0.124 \pm 0.002$ & 98 & - & - & - & 0.015 & 0 \\
\hline
\end{tabular}

* Value only given for information on the certificate. 
Table 2: Fish body size (fork length, $\mathrm{FL}$, in $\mathrm{cm}$ ) and trace metal concentrations (in $\mathrm{mg} \cdot \mathrm{kg}^{-1}$ dry mass) measured in the muscle of albacore tunas $(\mathrm{N}=443$ 1006 individuals) collected in 2013-2014 in the western Indian Ocean and in the south-eastern Atlantic Ocean. Values are means \pm standard deviation. Italic values 1007 are those per season and/or year of sampling, and bold values are those per geographic area.

\begin{tabular}{|c|c|c|c|c|c|c|c|c|c|c|}
\hline \multicolumn{2}{|c|}{$\begin{array}{c}\text { Area; Season and/or Year of } \\
\text { sampling; Sex }\end{array}$} & $\mathbf{N}$ & FL & $\mathrm{Cr}$ & $\mathbf{N i}$ * & $\mathrm{Cu}$ & $\mathbf{Z n}$ & Cd & Hg & $\mathbf{P b}$ * \\
\hline \multicolumn{2}{|c|}{ Reunion Island (REU) } & 128 & $102 \pm 5$ & $0.53 \pm 0.06$ & $0.01 \pm 0.01$ & $0.84 \pm 0.20$ & $14.5 \pm 7.1$ & $0.07 \pm 0.03$ & $1.708 \pm 0.629$ & $0.01 \pm 0.03$ \\
\hline \multicolumn{2}{|l|}{$\begin{array}{l}\text { Season } 1 \\
\text { (Nov-Dec 2013) }\end{array}$} & 64 & $104 \pm 4$ & $0.51 \pm 0.06$ & $0.02 \pm 0.02$ & $0.71 \pm 0.15$ & $11.2 \pm 2.2$ & $0.06 \pm 0.02$ & $1.773 \pm 0.677$ & $0.01 \pm 0.01$ \\
\hline \multirow{3}{*}{$\begin{array}{l}\text { Season } 2 \\
\text { (May-July 2014) }\end{array}$} & $\begin{array}{r}\text { Females } \\
\text { Males }\end{array}$ & $\begin{array}{l}31 \\
33\end{array}$ & $\begin{array}{l}101 \pm 3 \\
107 \pm 3\end{array}$ & $\begin{array}{l}0.52 \pm 0.05 \\
0.50 \pm 0.07\end{array}$ & $\begin{array}{l}0.02 \pm 0.02 \\
0.02 \pm 0.02\end{array}$ & $\begin{array}{l}0.74 \pm 0.18 \\
0.69 \pm 0.13\end{array}$ & $\begin{array}{l}11.0 \pm 2.1 \\
11.5 \pm 2.2\end{array}$ & $\begin{array}{l}0.06 \pm 0.02 \\
0.06 \pm 0.02\end{array}$ & $\begin{array}{l}1.721 \pm 0.630 \\
1.821 \pm 0.725\end{array}$ & $\begin{array}{l}0.01 \pm 0.01 \\
0.01 \pm 0.01\end{array}$ \\
\hline & & 64 & $101 \pm 5$ & $0.54 \pm 0.05$ & $0.01 \pm 0.00$ & $0.98 \pm 0.14$ & $17.7 \pm 8.7$ & $0.08 \pm 0.03$ & $1.644 \pm 0.574$ & $0.01 \pm 0.04$ \\
\hline & $\begin{array}{r}\text { Females } \\
\text { Males }\end{array}$ & $\begin{array}{l}32 \\
32\end{array}$ & $\begin{array}{c}99 \pm 4 \\
104 \pm 4\end{array}$ & $\begin{array}{l}0.54 \pm 0.05 \\
0.55 \pm 0.05\end{array}$ & $\begin{array}{l}0.00 \pm 0.00 \\
0.01 \pm 0.00\end{array}$ & $\begin{array}{l}0.96 \pm 0.15 \\
1.00 \pm 0.12\end{array}$ & $\begin{array}{c}20.0 \pm 11.6 \\
15.4 \pm 2.7\end{array}$ & $\begin{array}{l}0.07 \pm 0.02 \\
0.08 \pm 0.03\end{array}$ & $\begin{array}{l}1.405 \pm 0.392 \\
1.882 \pm 0.631\end{array}$ & $\begin{array}{l}0.00 \pm 0.00 \\
0.01 \pm 0.05\end{array}$ \\
\hline \multicolumn{2}{|c|}{ Seychelles (SEY) } & 118 & $96 \pm 5$ & $0.52 \pm 0.04$ & $0.01 \pm 0.01$ & $0.64 \pm 0.11$ & $11.3 \pm 2.2$ & $0.09 \pm 0.16$ & $1.403 \pm 0.406$ & $0.00 \pm 0.00$ \\
\hline \multirow{2}{*}{$\begin{array}{l}\text { Season 2-Year } 1 \\
\text { (June-July 2013) }\end{array}$} & & 50 & $96 \pm 5$ & $0.50 \pm 0.04$ & $0.01 \pm 0.01$ & $0.67 \pm 0.14$ & $12.3 \pm 2.9$ & $0.16 \pm 0.22$ & $1.310 \pm 0.306$ & $0.01 \pm 0.00$ \\
\hline & $\begin{array}{r}\text { Females } \\
\text { Males }\end{array}$ & $\begin{array}{l}20 \\
30\end{array}$ & $\begin{array}{l}95 \pm 4 \\
98 \pm 5\end{array}$ & $\begin{array}{l}0.51 \pm 0.05 \\
0.50 \pm 0.03\end{array}$ & $\begin{array}{l}0.01 \pm 0.01 \\
0.01 \pm 0.01\end{array}$ & $\begin{array}{l}0.64 \pm 0.12 \\
0.68 \pm 0.15\end{array}$ & $\begin{array}{l}12.5 \pm 2.0 \\
12.2 \pm 3.4\end{array}$ & $\begin{array}{l}0.15 \pm 0.13 \\
0.17 \pm 0.27\end{array}$ & $\begin{array}{l}1.302 \pm 0.220 \\
1.316 \pm 0.356\end{array}$ & $\begin{array}{l}0.01 \pm 0.00 \\
0.01 \pm 0.01\end{array}$ \\
\hline \multirow{2}{*}{$\begin{array}{l}\text { Season 2-Year } 2 \\
\text { (April 2014) }\end{array}$} & & 68 & $96 \pm 5$ & $0.53 \pm 0.03$ & $0.01 \pm 0.01$ & $0.62 \pm 0.09$ & $10.6 \pm 1.0$ & $0.04 \pm 0.01$ & $1.471 \pm 0.457$ & $0.00 \pm 0.00$ \\
\hline & $\begin{array}{r}\text { Females } \\
\text { Males }\end{array}$ & $\begin{array}{l}36 \\
32\end{array}$ & $\begin{array}{l}94 \pm 5 \\
99 \pm 4\end{array}$ & $\begin{array}{l}0.53 \pm 0.03 \\
0.53 \pm 0.03\end{array}$ & $\begin{array}{l}0.01 \pm 0.01 \\
0.01 \pm 0.01\end{array}$ & $\begin{array}{l}0.61 \pm 0.10 \\
0.63 \pm 0.08\end{array}$ & $\begin{array}{l}10.7 \pm 1.1 \\
10.4 \pm 0.9\end{array}$ & $\begin{array}{l}0.04 \pm 0.01 \\
0.04 \pm 0.01\end{array}$ & $\begin{array}{l}1.364 \pm 0.427 \\
1.592 \pm 0.465\end{array}$ & $\begin{array}{l}0.00 \pm 0.00 \\
0.00 \pm 0.00\end{array}$ \\
\hline \multicolumn{2}{|c|}{ South Africa (SA) } & 197 & $87 \pm 8$ & $0.53 \pm 0.08$ & $0.04 \pm 0.04$ & $1.55 \pm 0.38$ & $23.3 \pm 8.3$ & $0.34 \pm 0.26$ & $0.958 \pm 0.443$ & $0.01 \pm 0.02$ \\
\hline \multirow{2}{*}{$\begin{array}{l}\text { Season } 1 \\
\text { (Nov-Dec 2013) }\end{array}$} & & 98 & $83 \pm 4$ & $0.46 \pm 0.04$ & $0.04 \pm 0.04$ & $1.69 \pm 0.43$ & $26.4 \pm 9.5$ & $0.37 \pm 0.25$ & $0.795 \pm 0.151$ & $0.01 \pm 0.02$ \\
\hline & $\begin{array}{r}\text { Females } \\
\text { Males }\end{array}$ & $\begin{array}{l}50 \\
48\end{array}$ & $\begin{array}{l}83 \pm 4 \\
83 \pm 4\end{array}$ & $\begin{array}{l}0.46 \pm 0.04 \\
0.45 \pm 0.04\end{array}$ & $\begin{array}{l}0.04 \pm 0.04 \\
0.03 \pm 0.03\end{array}$ & $\begin{array}{l}1.70 \pm 0.42 \\
1.69 \pm 0.45\end{array}$ & $\begin{array}{c}25.0 \pm 7.7 \\
27.9 \pm 10.9\end{array}$ & $\begin{array}{l}0.37 \pm 0.26 \\
0.38 \pm 0.23\end{array}$ & $\begin{array}{l}0.759 \pm 0.143 \\
0.833 \pm 0.151\end{array}$ & $\begin{array}{l}0.01 \pm 0.02 \\
0.01 \pm 0.02\end{array}$ \\
\hline \multirow[t]{2}{*}{$\begin{array}{l}\text { Season } 2 \\
\text { (April-May 2014) }\end{array}$} & & 99 & $90 \pm 9$ & $0.59 \pm 0.05$ & $0.04 \pm 0.04$ & $1.42 \pm 0.25$ & $20.2 \pm 5.4$ & $0.30 \pm 0.26$ & $1.120 \pm 0.562$ & $0.02 \pm 0.02$ \\
\hline & $\begin{array}{r}\text { Females } \\
\text { Males }\end{array}$ & $\begin{array}{l}51 \\
48\end{array}$ & $\begin{array}{c}90 \pm 9 \\
91 \pm 10\end{array}$ & $\begin{array}{l}0.60 \pm 0.05 \\
0.59 \pm 0.05\end{array}$ & $\begin{array}{l}0.04 \pm 0.05 \\
0.03 \pm 0.02\end{array}$ & $\begin{array}{l}1.44 \pm 0.23 \\
1.40 \pm 0.27\end{array}$ & $\begin{array}{l}20.8 \pm 6.8 \\
19.5 \pm 3.4\end{array}$ & $\begin{array}{l}0.30 \pm 0.22 \\
0.30 \pm 0.30\end{array}$ & $\begin{array}{l}1.093 \pm 0.444 \\
1.150 \pm 0.669\end{array}$ & $\begin{array}{l}0.01 \pm 0.01 \\
0.02 \pm 0.02\end{array}$ \\
\hline
\end{tabular}


1010 Table 3: Results for the discriminant analyses (DAs) applied to evaluate the potential of trace metals and/or their combination with trophic markers $\left(\delta^{13} \mathrm{C}\right.$ and $1011 \delta^{15} \mathrm{~N}$ values) in discriminating albacore tunas from different geographic areas. The correlation coefficients between the discriminant functions and each of the

1012 original variables (trace metal or isotope value) included in DAs - also called «canonical correlation coefficients » (ccc) - are given, and help assess the

1013 relative importance of each variable for the discrimination of individuals along the axes. The coefficients of linear discriminants for axis 1 and/or 2 - also

1014 called «standardised discrimination coefficients» (sdc) - are given as well, and can be used for reconstructing equations of the DAs (Zuur et al., 2007).

1015 Variables with $\operatorname{ccc}>0.50$ (absolute value) are in bold.

\begin{tabular}{|c|c|c|c|}
\hline $\begin{array}{l}\text { DA: variables used; number of areas } \\
\text { considered (number of individuals) }\end{array}$ & $\begin{array}{l}\% \text { of well-classified } \\
\text { individuals for each area }\end{array}$ & $\begin{array}{l}\text { Order of importance of variables (cce; sdc) } \\
\text { for discrimination along the first axis of DA }\end{array}$ & $\begin{array}{l}\text { Order of importance of variables (cce; sde) } \\
\text { for discrimination along the second axis of DAA }\end{array}$ \\
\hline $\begin{array}{l}\text { DA 1: } 5 \text { trace metals; } 3 \text { areas } \\
(N=443)\end{array}$ & $\begin{array}{l}\text { REU }=69 \% \\
\text { SEY }=83 \% \\
\text { SA }=93 \%\end{array}$ & $\begin{array}{c}\mathbf{C u}(0.98 ; 1.49)>\mathbf{Z n}(0.72 ; 0.16)>\mathbf{C d}(0.65 ; 0.10) \\
\quad>\mathbf{H g}(-0.57 ;-0.32)>\operatorname{Cr}(0.05 ; 0.17)\end{array}$ & $\begin{array}{c}\mathbf{H g}(0.71 ; 1.00)>\mathrm{Cd}(-0.30 ;-0.65)>\mathrm{Zn}(0.17 ; 0.20) \\
>\mathrm{Cu}(0.14 ; 0.87)>\operatorname{Cr}(0.10 ; 0.02)\end{array}$ \\
\hline $\begin{array}{l}\text { DA 2: } 5 \text { trace metals; } 2 \text { areas } \\
(\mathbf{N}=246)\end{array}$ & $\begin{array}{l}\text { REU }=73 \% \\
\mathrm{SEY}=89 \%\end{array}$ & $\begin{aligned} \mathbf{C u}(-0.86 ; & -1.14)>\mathrm{Zn}(-0.46 ;-0.04)>\mathrm{Hg}(-0.45 ;-0.45) \\
& >\mathrm{Cd}(0.18 ; 0.44)>\operatorname{Cr}(-0.12 ; 0.09)\end{aligned}$ & - \\
\hline $\begin{array}{c}\text { DA 3: } 5 \text { trace metals }+\delta^{13} \mathrm{C}+\delta^{15} \mathrm{~N} ; 3 \text { areas } \\
(\mathrm{N}=335)\end{array}$ & $\begin{array}{l}\text { REU }=84 \% \\
\text { SEY }=60 \% \\
\text { SA }=100 \%\end{array}$ & $\begin{aligned} \delta^{15} \mathbf{N} & (0.92 ; 1.57)>\mathbf{C u}(0.86 ; 0.74)>\mathbf{Z n}(0.68 ; 0.16) \\
& >\mathbf{H g}(-0.56 ;-0.33)>\mathbf{C d}(0.54 ;-0.01) \\
& >\delta^{13} \mathrm{C}(-0.15 ;-0.38)>\operatorname{Cr}(0.06 ; 0.14)\end{aligned}$ & $\begin{aligned} \mathrm{Hg}(0.44 ; 0.78)> & \delta^{13} \mathrm{C}(-0.37 ;-0.39)>\mathrm{Cu}(0.31 ; 1.21) \\
>\mathrm{Zn}(0.24 ; 0.15)> & \delta^{15} \mathrm{~N}(-0.17 ;-0.56)>\mathrm{Cd}(0.13 ;-0.49) \\
& >\mathrm{Cr}(0.07 ; 0.21)\end{aligned}$ \\
\hline $\begin{array}{c}\text { DA 4: } 5 \text { trace metals }+\delta^{13} \mathrm{C}+\delta^{15} \mathrm{~N} ; 2 \text { areas } \\
(\mathrm{N}=159)\end{array}$ & $\begin{array}{l}\mathrm{REU}=83 \% \\
\mathrm{SEY}=78 \%\end{array}$ & $\begin{array}{c}\text { Cu }(-0.63 ;-0.80)>\operatorname{Hg}(-0.44 ;-0.56)>\delta^{13} \mathrm{C}(0.38 ; 0.59) \\
>\delta^{15} \mathrm{~N}(0.35 ; 0.39)>\operatorname{Zn}(-0.35 ;-0.25)>\operatorname{Cd}(0.26 ; 0.45) \\
>\operatorname{Cr}(-0.08 ; 0.07)\end{array}$ & - \\
\hline
\end{tabular}

\section{$10 \overline{16}$}


Table 4: Values for additional tracers considered and measured on a subsample of individuals analysed for trace elements: trophic markers $\left(\delta^{13} \mathrm{C}, \delta^{15} \mathrm{~N}\right.$, in $\%$ o

1020 per season and/or year of sampling, and bold values are those per geographic area.

\begin{tabular}{|c|c|c|c|c|c|c|c|c|}
\hline \multirow{2}{*}{\multicolumn{2}{|c|}{$\begin{array}{l}\text { Area; Season and/or Year of } \\
\text { sampling; Sex }\end{array}$}} & \multicolumn{4}{|c|}{ Trophic markers $\left(\delta^{13} \mathrm{C}, \delta^{15} \mathrm{~N}\right)^{\mathrm{a}}$} & \multicolumn{3}{|c|}{ POPs (ratios) ${ }^{a}$} \\
\hline & & $\mathbf{N}$ & $\delta^{13} \mathrm{C}$ & $\delta^{15} \mathrm{~N}$ & $\mathbf{N}$ & $\begin{array}{l}\text { Sum DDTs / } \\
\text { Sum PCBs }{ }^{b}\end{array}$ & $\begin{array}{l}p, p{ }^{\prime} \text { DDT / } \\
p, p ' p^{\prime}{ }^{c}\end{array}$ & $\begin{array}{l}o, p, \text { DDT } \\
p, p, \text { DDT }\end{array}$ \\
\hline \multicolumn{2}{|c|}{ Reunion Island (REU) } & 96 & $-17.42 \pm 0.33$ & $12.06 \pm 0.56$ & & & & \\
\hline \multicolumn{2}{|l|}{$\begin{array}{l}\text { Season } 1 \\
\text { (Nov-Dec 2013) }\end{array}$} & 49 & $-17.54 \pm 0.34$ & $12.01 \pm 0.58$ & 43 & $2.83 \pm 1.11$ & $0.26 \pm 0.14$ & $0.31 \pm 0.09$ \\
\hline \multirow{3}{*}{$\begin{array}{l}\text { Season } 2 \\
\text { (May-July 2014) }\end{array}$} & $\begin{array}{r}\text { Females } \\
\text { Males }\end{array}$ & $\begin{array}{l}24 \\
25\end{array}$ & $\begin{array}{l}-17.74 \pm 0.32 \\
-17.35 \pm 0.23\end{array}$ & $\begin{array}{l}11.96 \pm 0.63 \\
12.07 \pm 0.54\end{array}$ & $\begin{array}{l}21 \\
22\end{array}$ & $\begin{array}{l}3.44 \pm 1.05 \\
2.25 \pm 0.83\end{array}$ & $\begin{array}{l}0.35 \pm 0.13 \\
0.17 \pm 0.09\end{array}$ & $\begin{array}{l}0.28 \pm 0.09 \\
0.34 \pm 0.09\end{array}$ \\
\hline & & 47 & $-17.30 \pm 0.27$ & $12.11 \pm 0.55$ & - & - & - & - \\
\hline & $\begin{array}{r}\text { Females } \\
\text { Males }\end{array}$ & $\begin{array}{l}23 \\
24\end{array}$ & $\begin{array}{l}-17.38 \pm 0.26 \\
-17.22 \pm 0.27\end{array}$ & $\begin{array}{l}12.02 \pm 0.50 \\
12.20 \pm 0.59\end{array}$ & - & - & - & - \\
\hline \multicolumn{2}{|c|}{ Seychelles (SEY) } & 63 & $-17.26 \pm 0.27$ & $12.31 \pm 0.43$ & - & - & - & - \\
\hline \multirow[t]{2}{*}{$\begin{array}{l}\text { Season 2-Year } 1 \\
\text { (June-July 2013) }\end{array}$} & & 26 & $-17.40 \pm 0.33$ & $12.47 \pm 0.44$ & - & - & - & - \\
\hline & $\begin{array}{r}\text { Females } \\
\text { Males }\end{array}$ & $\begin{array}{l}11 \\
15\end{array}$ & $\begin{array}{l}-17.44 \pm 0.38 \\
-17.37 \pm 0.29\end{array}$ & $\begin{array}{l}12.37 \pm 0.58 \\
12.54 \pm 0.30\end{array}$ & - & - & - & - \\
\hline \multirow{3}{*}{$\begin{array}{l}\text { Season 2-Year } 2 \\
\text { (April 2014) }\end{array}$} & & 37 & $-17.16 \pm 0.17$ & $12.20 \pm 0.39$ & - & - & - & - \\
\hline & Females & 24 & $-17.18 \pm 0.18$ & $12.18 \pm 0.41$ & - & - & - & - \\
\hline & Males & 13 & $-17.14 \pm 0.16$ & $12.24 \pm 0.35$ & - & - & - & - \\
\hline \multicolumn{2}{|c|}{ South Africa (SA) } & 176 & $-17.47 \pm 0.43$ & $13.80 \pm 0.53$ & & & & \\
\hline \multirow{2}{*}{$\begin{array}{l}\text { Season } 1 \\
\text { (Nov-Dec 2013) }\end{array}$} & & 78 & $-17.62 \pm 0.41$ & $13.65 \pm 0.50$ & 43 & $3.02 \pm 0.66$ & $0.40 \pm 0.07$ & $0.17 \pm 0.02$ \\
\hline & $\begin{array}{r}\text { Females } \\
\text { Males }\end{array}$ & $\begin{array}{l}43 \\
35\end{array}$ & $\begin{array}{l}-17.59 \pm 0.44 \\
-17.65 \pm 0.38\end{array}$ & $\begin{array}{l}13.67 \pm 0.53 \\
13.63 \pm 0.46\end{array}$ & $\begin{array}{l}22 \\
21\end{array}$ & $\begin{array}{l}3.18 \pm 0.80 \\
2.85 \pm 0.44\end{array}$ & $\begin{array}{l}0.40 \pm 0.07 \\
0.40 \pm 0.07\end{array}$ & $\begin{array}{l}0.17 \pm 0.02 \\
0.16 \pm 0.02\end{array}$ \\
\hline \multirow{3}{*}{$\begin{array}{l}\text { Season } 2 \\
\text { (April-May 2014) }\end{array}$} & & 98 & $-17.34 \pm 0.40$ & $13.92 \pm 0.53$ & - & - & - & - \\
\hline & Females & 51 & $-17.38 \pm 0.40$ & $13.89 \pm 0.54$ & - & - & - & - \\
\hline & Males & 47 & $-17.30 \pm 0.39$ & $13.96 \pm 0.52$ & - & - & - & - \\
\hline
\end{tabular}

${ }^{a} \mathrm{~N}=335$ and 86 in total, for trophic markers and POPs respectively.

$1022 \mathrm{~b}$ "Sum PCBs/Sum DDTs" ratio: can generally distinguish the influence of sources from agricultural origin (when largely $>1$ ) vs. sources from industrial origin 1023 (Yogui et al., 2003; Lailson-Brito et al., 2011). 
c “ $p, p$ '-DDT/p,p'-DDE” ratio: can trace the residence time and degree of degradation of DDT in the environment, and consequently distinguish new vs. old DDT sources (Suárez et al., 2013)

1026 d "o,p'-DDT/p,p'-DDT" ratio: can trace the DTT origin (close to the technical mixture (0.2-0.3), or not; Kalantzi et al., 2001). 


\section{Caption to figures:}

Figure 1: Map of tuna sampling in different areas in the western Indian Ocean and in the south-eastern Atlantic Ocean, and over two seasons and/or years between June 2013 and July 2014. $\mathrm{REU}=$ Reunion Island; SEY =Seychelles; SA =South Africa. Light colours correspond to a sampling over Season 1 (for REU and SA) or Season 2-Year 1 (for SEY), and dark colours to a sampling over Season 2 (for REU and SA) or Season 2-Year 2 (for SEY). Main regional currents (from Schott et al., 2009) are also indicated: SECC $=$ South Equatorial Counter Current; NEMC =Northeast Madagascar Current; SEMC $=$ Southeast Madagascar Current; SC:=Somali Current; SG =Southern Gyre; $\mathrm{AC}=$ Agulhas Current; $\mathrm{AR}=$ Agulhas Current Retroflexion; $\mathrm{BC}=$ Benguela Current. "Sample size" indicates the number of individuals collected in each area.

Figure 2: Boxplots of raw and size-normalised (to a 95cm-individual) trace metal concentrations measured in the study tunas $(\mathrm{N}=443)$, excluding the elements $\mathrm{Ni}$ and $\mathrm{Pb}$ for which most of values were under limits of quantification (see section 2.4). The box width is function of the number of individuals in each group considered. The box length represents the interquartile, the bar length represents the range, and the horizontal lines in bold are median values. A same letter indicates that areas are not significantly different (results of the post-hoc multiple comparison test with Holm adjustment method, after Kruskal-Wallis test). Following Student t-tests or Mann-Whitney-Wilcoxon tests performed, stars indicate significant differences between sexes (in a given season and/or year, and in a given area), or significant differences between seasons/years of sampling in a given area (with $* \mathrm{p}<0.05 ; * * \mathrm{p}<0.01 ; * * * \mathrm{p}<0.001)$. For the non-essential elements $\mathrm{Cd}$ and $\mathrm{Hg}$, the maximum safety concentration limits (EC, 2006) are also indicated in red dashed lines, considering average $70 \%$ moisture content in tuna flesh. $\mathrm{F}=$ Females; $\mathrm{M}=$ Males; $\mathrm{S} 1=$ Season 1; $\mathrm{S} 2=\mathrm{Season} 2$; $\mathrm{S} 2-$ Y1 =Season 2-Year 1; S2-Y2 =Season 2-Year 2.

Figure 3: Projection of variables and individuals on the first two components resulting from the principal component analyses (PCAs) 1-3 performed (PCA 1: including only the 5 trace metals above limits of quantification; PCA 2: 5 trace metals + trophic markers $\delta^{13} \mathrm{C}$ and $\delta^{15} \mathrm{~N}$; PCA 3: 5 trace metals + POP ratios). For each PCA, the top figure corresponds to the correlation biplot showing the distribution of variables. For a given variable, the length of the line shows how well it is represented by the 2-dimensional approximation, and reflects its contribution to the first two principal components (horizontal axis: principal component 1; vertical axis: principal component 2; and the variability explained by each axis is given). Variables pointing in the same direction display a high positive correlation; variables pointing in the opposite direction have a high negative correlation; and variables with an angle of $90^{\circ}$ have a small correlation close to 0 . For each PCA, the middle figure corresponds to the projection of individuals on the correlation biplot, with a grouping of individuals by sex. The bottom figure finally corresponds to the projection of individuals on the correlation biplot as well, but with a grouping of individuals by area and season and/or year of sampling. $\mathrm{N}=$ number of individuals included in each PCA; $\mathrm{F}=$ Females; $\mathrm{M}=$ Males; $\mathrm{S} 1=$ Season 1; $\mathrm{S} 2$ =Season 2; $\mathrm{S} 2-\mathrm{Y} 1=$ Season 2Year 1; S2-Y2 =Season 2-Year 2; REU =Reunion Island; SEY =Seychelles; SA =South Africa.

Figure 4: Relationships between muscle log-transformed metal concentrations and body size (FL; left panel) or $\delta^{15} \mathrm{~N}$ values (right panel) in the study tunas $(\mathrm{N}=443$ when FL considered; $\mathrm{N}=335$ when $\delta^{15} \mathrm{~N}$ ). Results from the GLM models (lines) are plotted on observed data (models fitted to individual log-transformed metal concentrations to identify size-related or diet $\delta^{15} \mathrm{~N}$-related trends, and the confounding effect of sex, season/year and area of sampling for explaining trace metal concentrations variability). As the factor Area/Season-Year of sampling (Area/S-Y) was always significant in the final GLMs, one line per modality of the factor Area/S-Y is presented. S1 =Season 1; S2 =Season 2; S2-Y1 =Season 2-Year 1; S2-Y2 =Season 2-Year 2. When the interaction term was not significant, lines are parallel. Results for models that did not comply with necessary assumptions are not presented (i.e. for Cd). 


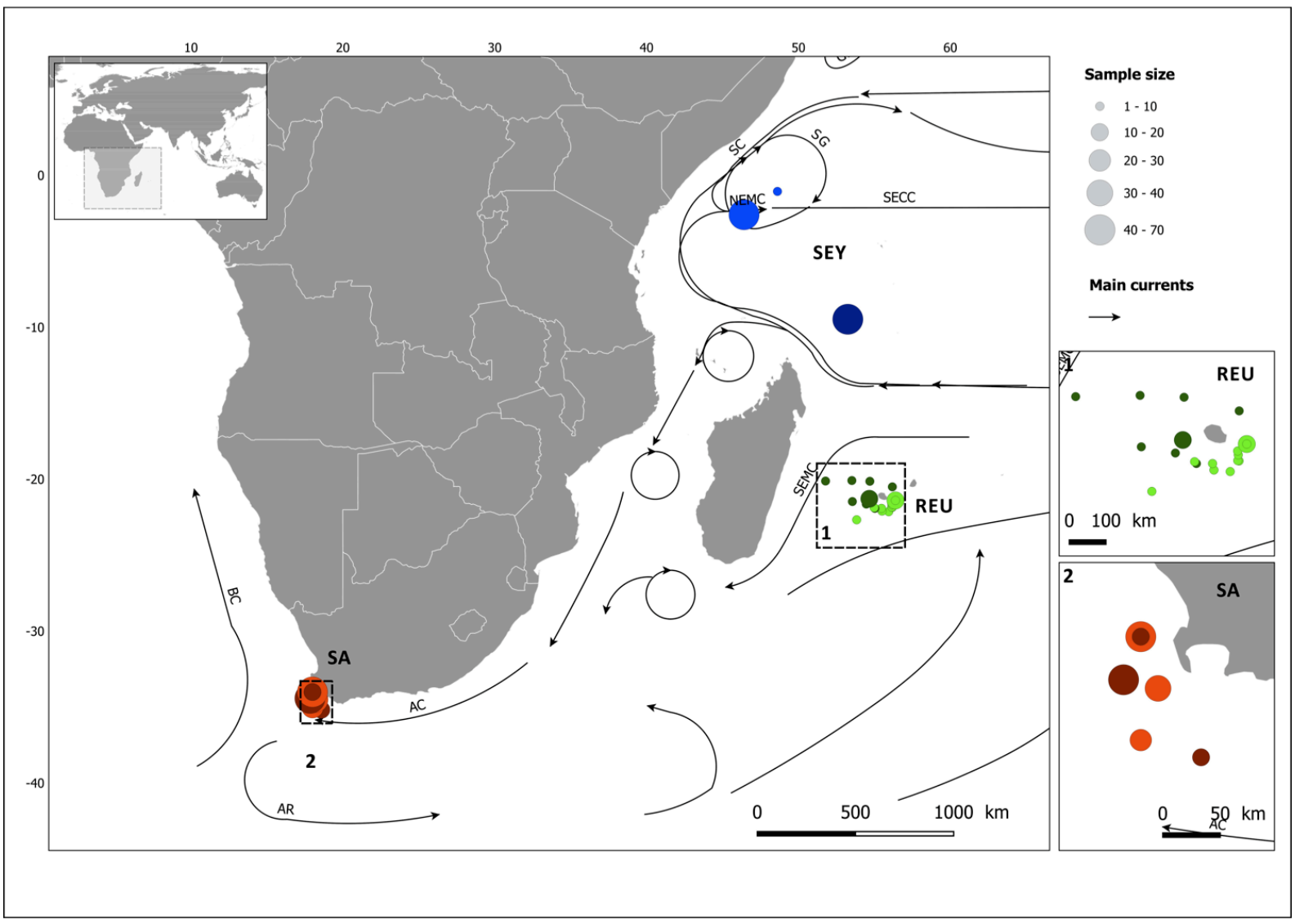

1081

1082

1083

Figure 1

1084 


\section{Raw data}
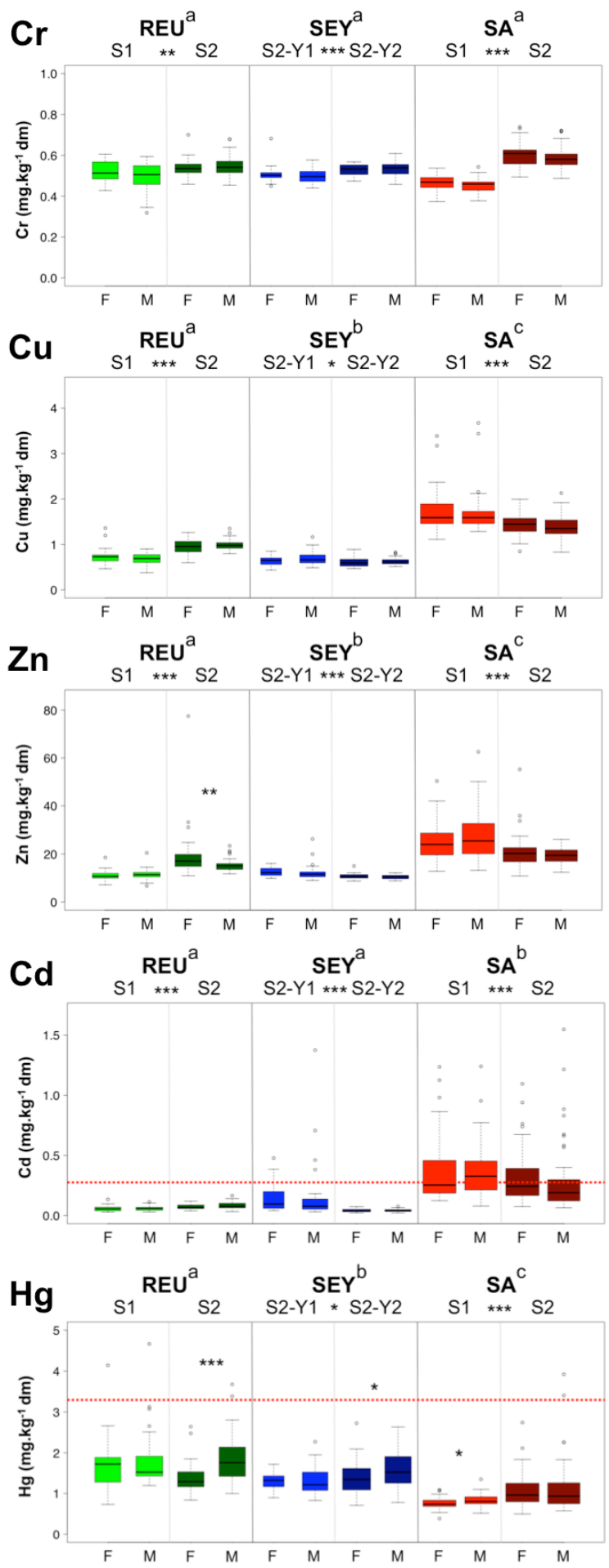

Size (FL)-normalised data

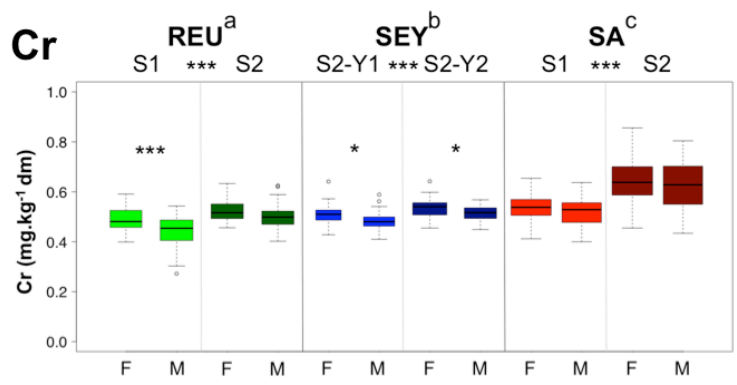

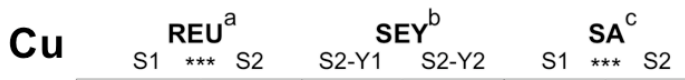

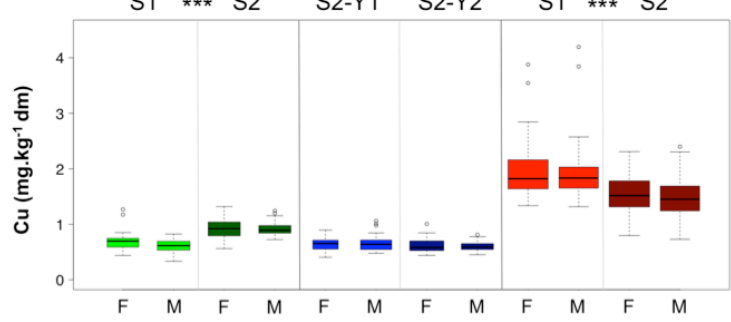

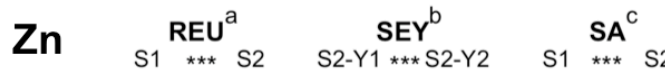

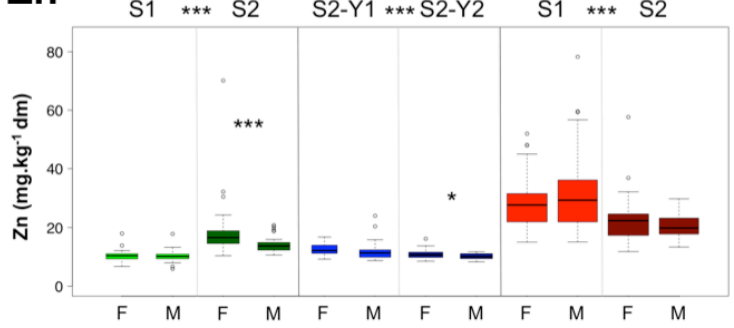

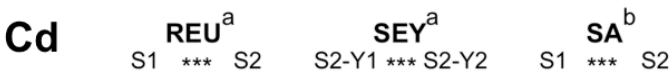

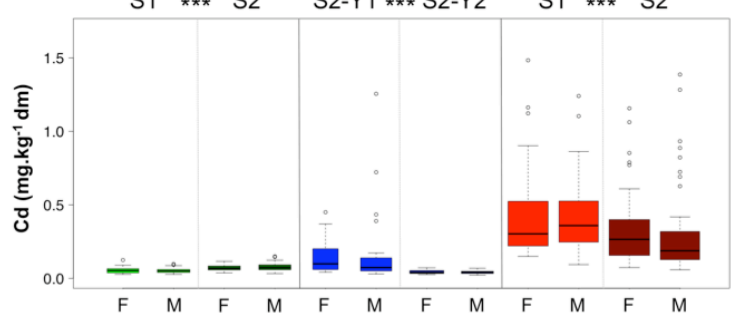

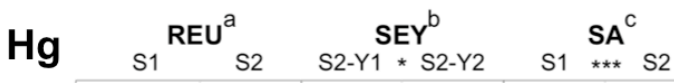

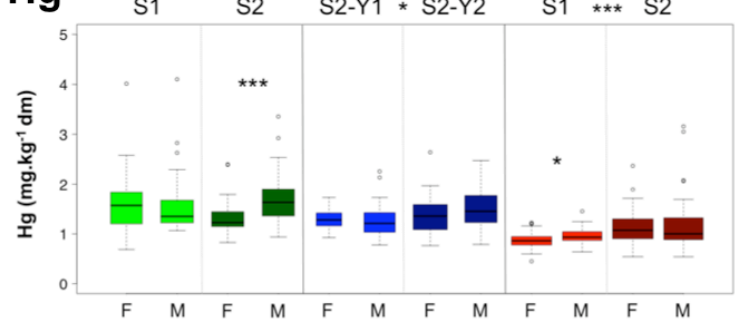




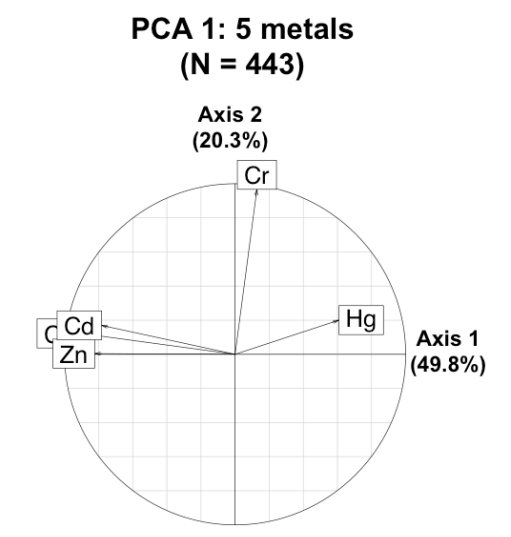

PCA 2: 5 metals $+\delta^{13} \mathrm{C}+\delta^{15} \mathrm{~N}$

PCA 3: 5 metals + POPs

$(\mathrm{N}=443)$

( $\mathrm{N}=335)$

$(\mathrm{N}=86)$
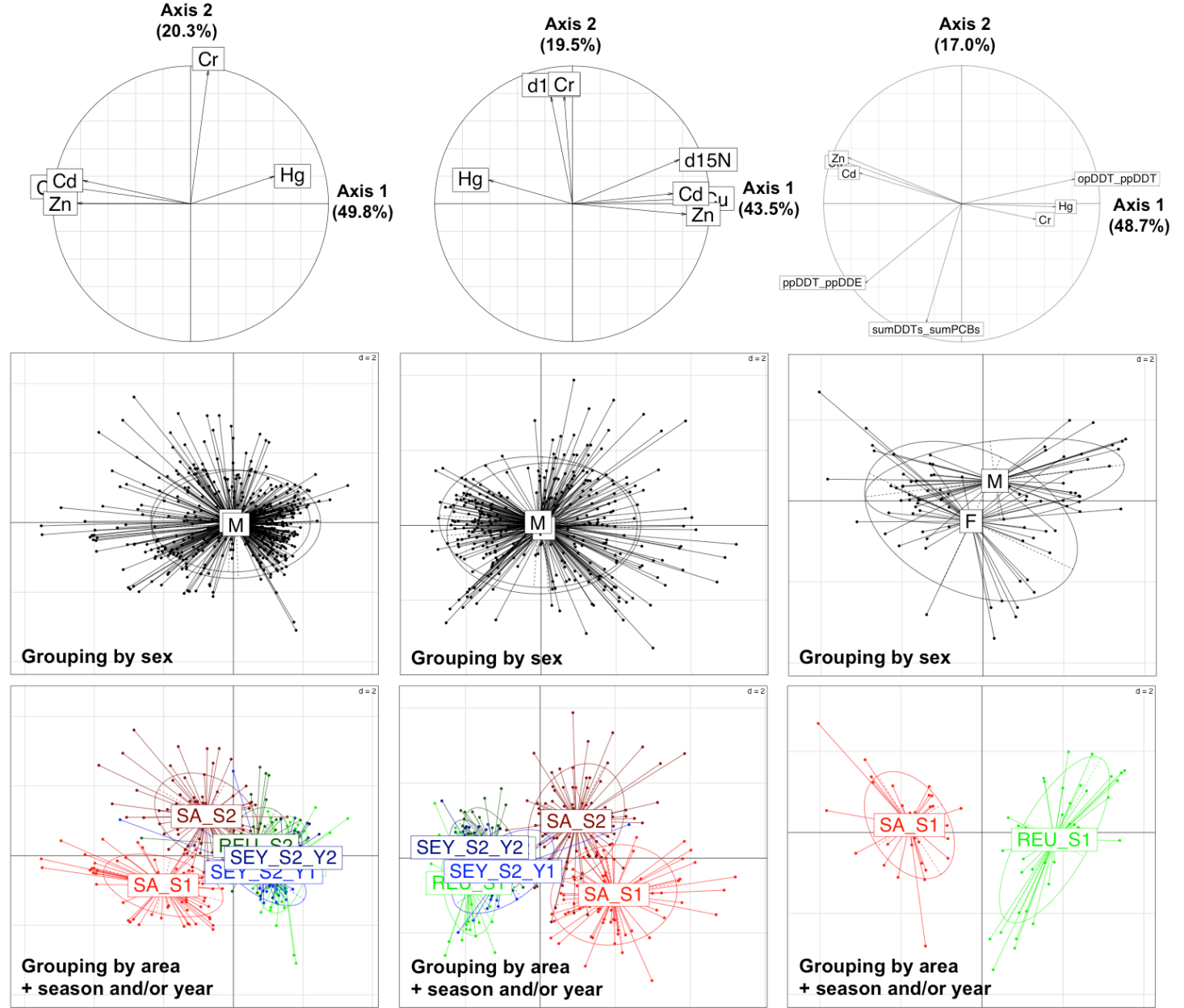

Grouping by area

+ season and/or year

Grouping by area

+ season and/or year

Grouping by area

\section{Figure 3}



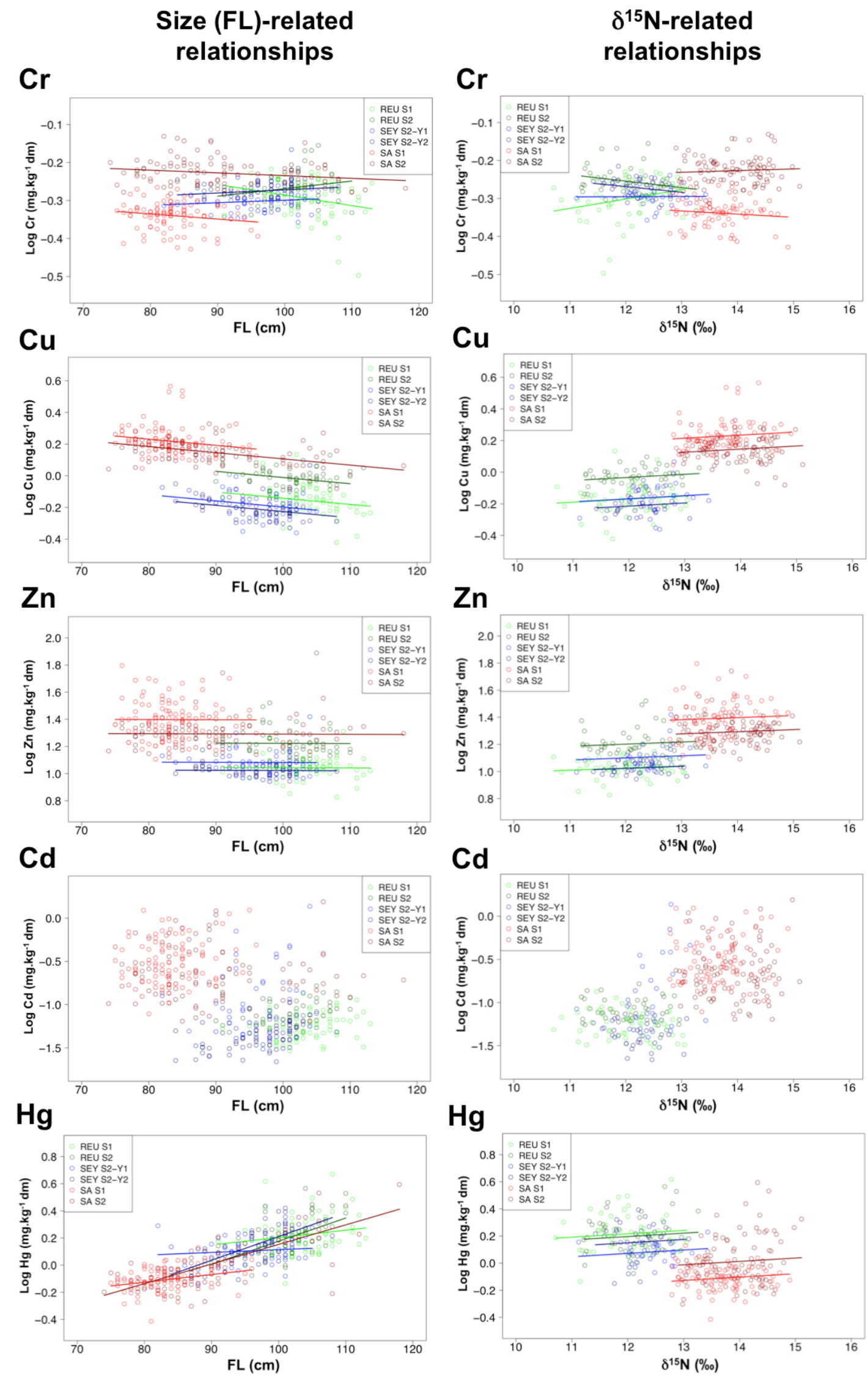